\title{
The WAIS Divide deep ice core WD2014 chronology - Part 1: Methane synchronization (68-31 ka BP) and the gas age-ice age difference
}

\author{
C. Buizert ${ }^{1}$, K. M. Cuffey ${ }^{2}$, J. P. Severinghaus ${ }^{3}$, D. Baggenstos ${ }^{3}$, T. J. Fudge ${ }^{4}$, E. J. Steig ${ }^{4}$, B. R. Markle ${ }^{4}$, \\ M. Winstrup ${ }^{4}$, R. H. Rhodes ${ }^{1}$, E. J. Brook ${ }^{1}$, T. A. Sowers ${ }^{5}$, G. D. Clow $^{6}$, H. Cheng ${ }^{7,8}$, R. L. Edwards ${ }^{8}$, M. Sigl ${ }^{9}$, \\ J. R. McConnell ${ }^{9}$, and K. C. Taylor ${ }^{9}$ \\ ${ }^{1}$ College of Earth, Ocean, and Atmospheric Sciences, Oregon State University, Corvallis, OR 97331, USA \\ ${ }^{2}$ Department of Geography, University of California, Berkeley, CA 94720, USA \\ ${ }^{3}$ Scripps Institution of Oceanography, University of California, San Diego, La Jolla, CA 92093, USA \\ ${ }^{4}$ Quaternary Research Center and Department of Earth and Space Sciences, University of Washington, Seattle, \\ WA 98195, USA \\ ${ }^{5}$ Department of Geosciences and Earth and Environmental Systems Institute, Pennsylvania State University, \\ University Park, PA 16802, USA \\ ${ }^{6}$ US Geological Survey, Boulder, CO 80309, USA \\ ${ }^{7}$ Institute of Global Environmental Change, Xi' an Jiaotong University, Xi' an 710049, China \\ ${ }^{8}$ Department of Geology and Geophysics, University of Minnesota, Minneapolis, MN 55455, USA \\ ${ }^{9}$ Desert Research Institute, Nevada System of Higher Education, Reno, NV 89512, USA
}

Correspondence to: C. Buizert (buizertc@ science.oregonstate.edu)

Received: 1 August 2014 - Published in Clim. Past Discuss.: 28 August 2014

Revised: 24 December 2014 - Accepted: 7 January 2015 - Published: 5 February 2015

\begin{abstract}
The West Antarctic Ice Sheet Divide (WAIS Divide, WD) ice core is a newly drilled, high-accumulation deep ice core that provides Antarctic climate records of the past $\sim 68 \mathrm{ka}$ at unprecedented temporal resolution. The upper $2850 \mathrm{~m}$ (back to $31.2 \mathrm{ka} \mathrm{BP}$ ) have been dated using annual-layer counting. Here we present a chronology for the deep part of the core (67.8-31.2 ka BP), which is based on stratigraphic matching to annual-layer-counted Greenland ice cores using globally well-mixed atmospheric methane. We calculate the WD gas age-ice age difference $(\Delta$ age $)$ using a combination of firn densification modeling, ice-flow modeling, and a data set of $\delta^{15} \mathrm{~N}-\mathrm{N}_{2}$, a proxy for past firn column thickness. The largest $\Delta$ age at WD occurs during the Last Glacial Maximum, and is $525 \pm 120$ years. Internally consistent solutions can be found only when assuming little to no influence of impurity content on densification rates, contrary to a recently proposed hypothesis. We synchronize the WD chronology to a linearly scaled version of the layer-counted Greenland Ice Core Chronology (GICC05),
\end{abstract}

which brings the age of Dansgaard-Oeschger (DO) events into agreement with the $\mathrm{U} / \mathrm{Th}$ absolutely dated Hulu Cave speleothem record. The small $\Delta$ age at WD provides valuable opportunities to investigate the timing of atmospheric greenhouse gas variations relative to Antarctic climate, as well as the interhemispheric phasing of the "bipolar seesaw".

\section{Introduction}

Deep ice cores from the polar regions provide highresolution climate records of past atmospheric composition, aerosol loading and polar temperatures (e.g., NGRIP community members, 2004; EPICA Community Members, 2006; Wolff et al., 2006; Ahn and Brook, 2008). Furthermore, the coring itself gives access to the ice sheet interior and bed, allowing investigation of glaciologically important processes such as ice deformation (Gundestrup et al., 1993), folding (NEEM community members, 2013), crystal fabric evolution 
(Gow et al., 1997), and geothermal heat flow (Dahl-Jensen et al., 1998). Having a reliable ice core chronology (i.e., an age-depth relationship) is paramount for the interpretation of the climate records and comparison to marine and terrestrial paleoclimate archives.

The West Antarctic Ice Sheet Divide (WAIS Divide, WD) ice core $\left(79.48^{\circ} \mathrm{S}, 112.11^{\circ} \mathrm{W} ; 1766 \mathrm{~m}\right.$ above sea level; $-30^{\circ} \mathrm{C}$ present-day mean annual temperature) was drilled and recovered to $3404 \mathrm{~m}$ depth (WAIS Divide Project Members, 2013). Drilling was stopped $50 \mathrm{~m}$ above the estimated bedrock depth to prevent contamination of the basal hydrology. Due to high accumulation rates of $22 \mathrm{cmice}^{-1}$ at present and $\sim 10 \mathrm{~cm}$ ice $\mathrm{a}^{-1}$ during the Last Glacial Maximum (LGM), the WD core delivers climate records of unprecedented temporal resolution (Steig et al., 2013; Sigl et al., 2013) as well as gas records that are only minimally affected by diffusive smoothing in the firn column (Mischler et al., 2009; Mitchell et al., 2011, 2013; Marcott et al., 2014). The combination of high accumulation rates and basal melting at the WD site results in ice near the bed that is relatively young $(\sim 68 \mathrm{ka})$ compared to cores drilled in central East Antarctica.

In WD, annual layers can be identified reliably for the upper $2850 \mathrm{~m}$ of the core, reaching back to $31.2 \mathrm{kaBP}$ (thousands of years before present, with present defined as $1950 \mathrm{CE})$. Below $2850 \mathrm{~m}$ depth an alternative dating strategy is needed. Several methods have been employed previously at other deep ice core sites. First, orbital tuning via $\delta \mathrm{O}_{2} / \mathrm{N}_{2}$ has been applied successfully to several Antarctic cores (Bender, 2002; Kawamura et al., 2007). However, an age span of only $\sim 3$ precessional cycles in WD, in combination with the low signal-to-noise ratio of $\delta \mathrm{O}_{2} / \mathrm{N}_{2}$ data, makes this technique unsuitable for WD. The uncertainty in the orbital tuning is about one-fourth of a precessional cycle $(\sim 5 \mathrm{ka})$, making it a relatively low-resolution dating tool. Second, in Greenland, ice-flow modeling has been used to extend layer-counted chronologies (e.g., Johnsen et al., 2001; Wolff et al., 2010). This method requires assumptions about past accumulation rates, ice flow, and ice sheet elevation. Particularly for the oldest WD ice, the resulting uncertainty would be substantial. Third, several radiometric techniques have been proposed to date ancient ice. Radiocarbon $\left({ }^{14} \mathrm{C}\right)$ dating of atmospheric $\mathrm{CO}_{2}$ trapped in the ice is unsuitable as it suffers from in situ cosmogenic production in the firn (Lal et al., 1990), and the oldest WD ice dates beyond the reach of ${ }^{14} \mathrm{C}$ dating. Other absolute (radiometric) dating techniques, such as recoil ${ }^{234} \mathrm{U}$ dating (Aciego et al., 2011), ${ }^{81} \mathrm{Kr}$ dating (Buizert et al., 2014a), or atmospheric ${ }^{40}$ Ar buildup (Bender et al., 2008), currently suffer from uncertainties that are too large ( $\geq 20 \mathrm{ka}$ ) to make them applicable at WD.

Instead, at WD we use stratigraphic matching to welldated Greenland ice cores using globally well-mixed atmospheric methane $\left(\mathrm{CH}_{4}\right)$ mixing ratios (Blunier et al., 1998; Blunier and Brook, 2001; Blunier et al., 2007; Petrenko et al., 2006; EPICA Community Members, 2006; Capron et al., 2010). This method is particularly suited to WD because of the small gas age-ice age difference ( $\Delta$ age, Sect. 3 ) and the high-resolution, high-precision $\mathrm{CH}_{4}$ record available (Sect. 2.1). The method has three main sources of uncertainty: (i) the age uncertainty in the records one synchronizes to, (ii) $\Delta$ age of the ice core being dated, and (iii) the interpolation scheme used in between the $\mathrm{CH}_{4}$ tie points. We present several improvements over previous work that reduce and quantify these uncertainties: (i) we combine the layercounted Greenland Ice Core Chronology (GICC05) and a recently refined version of the U / Th-dated Hulu speleothem record (Edwards et al., 2015; Reimer et al., 2013; Southon et al., 2012) to obtain a more accurate estimate of the (absolute) ages of abrupt Dansgaard-Oeschger (DO) events (Sect. 4.4); (ii) we combine firn densification modeling, iceflow modeling, a new WD $\delta^{15} \mathrm{~N}-\mathrm{N}_{2}$ data set that spans the entire core, and a Monte Carlo sensitivity study to obtain a reliable $\Delta$ age estimate (Sect. 3); and (iii) we compare four different interpolation schemes to obtain an objective estimate of the interpolation uncertainty (Sect. 4.5).

This work is the first part in a series of two papers describing the WD2014 chronology for the WD core in detail. The second part describes the development of the annual layer count from both multi-parameter chemistry and electrical conductivity measurements. The WD2014 chronology is currently the recommended gas and ice timescale for the WD deep core, and as such it supersedes the previously published WDC06A-7 chronology (WAIS Divide Project Members, 2013).

\section{Methods}

\subsection{Data description}

Measurements of water stable isotopes. Water isotopic composition $\left(\delta^{18} \mathrm{O}\right.$ and $\left.\delta \mathrm{D}=\delta^{2} \mathrm{H}\right)$ was measured at IsoLab, University of Washington. Procedures for the deep section of the core are identical to those used for the upper part of the core reported in WAIS Divide Project Members (2013) and Steig et al. (2013). Measurements were made at 0.25 to $0.5 \mathrm{~m}$ depth resolution using laser spectroscopy (Picarro L2120-i water isotope analyzer), and normalized to VSMOW-SLAP (Vienna Standard Mean Ocean Water - Standard Light Antarctic Precipitation). The precision of the measurements is better than 0.1 and $0.8 \%$ for $\delta^{18} \mathrm{O}$ and $\delta \mathrm{D}$, respectively.

Measurements of $\mathrm{CH}_{4}$. Two $\mathrm{CH}_{4}$ data sets were used for WD. The first is from discrete ice samples, and was measured jointly at Pennsylvania State University (0-68 ka, 0.5$2 \mathrm{~m}$ resolution) and Oregon State University (11.4-24.8 ka, 1-2 $\mathrm{m}$ resolution). Air was extracted from $\sim 50 \mathrm{~g}$ ice samples using a melt-refreeze technique, and analyzed on a standard gas chromatograph equipped with a flame-ionization detector. Corrections for solubility, blank size and gravitational enrichment are applied (Mitchell et al., 2011; WAIS Divide 
Project Members, 2013). The second data set is a continuous $\mathrm{CH}_{4}$ record measured by coupling a laser spectrometer to a continuous flow analysis setup (Stowasser et al., 2012; Rhodes et al., 2013; Chappellaz et al., 2013), and was measured jointly by Oregon State University and the Desert Research Institute (Rhodes et al., 2015). The continuous data set is used to identify the abrupt DO transitions, as it provides better temporal resolution and analytical precision. Both records are reported on the NOAA04 scale (Dlugokencky et al., 2005). Analytical precision in the $\mathrm{CH}_{4}$ data $(2 \sigma$ pooled standard deviation) is around 3.2 and $14 \mathrm{ppb}$ for the discrete data from Oregon State University and Pennsylvania State University, respectively, and 3 to 8 ppb for the continuous $\mathrm{CH}_{4}$ data, depending on the analyzer used (Rhodes et al., 2015); the 14 ppb stated for the PSU discrete data may be an overestimation, as depth-adjacent (rather than true replicate) samples were used in the analysis.

Measurements of $\delta^{15} \mathrm{~N}$. Atmospheric $\mathrm{N}_{2}$ isotopic composition $\left(\delta^{15} \mathrm{~N}\right)$ was measured at Scripps Institution of Oceanography, University of California. Air was extracted from $\sim$ 12 gram ice samples using a melt-refreeze technique, and collected in stainless steel tubes at liquid-He temperature. $\delta^{15} \mathrm{~N}$ was analyzed using conventional dual-inlet isotope ratio mass spectrometry (IRMS) on a Thermo Finnigan Delta $\mathrm{V}$ mass spectrometer. Results are normalized to La Jolla (California, USA) air, and routine analytical corrections are applied (Sowers et al., 1989; Petrenko et al., 2006; Severinghaus et al., 2009). Duplicates were not run for most $\delta^{15} \mathrm{~N}$ data in this study, but the pooled standard deviations of Holocene WD $\delta^{15} \mathrm{~N}$ data sets with duplicate analyses are $0.003 \%$ o (Orsi, 2013). We conservatively adopt an analytical uncertainty of $0.005 \%$ for this data set to allow for other sources of error.

Measurements of $[\mathrm{Ca}]$. Ca concentrations in the ice were measured at the Ultra Trace Chemistry Laboratory at the Desert Research Institute via continuous flow analysis. Longitudinal samples of ice (approximately $100 \mathrm{~cm} \times 3.3 \mathrm{~cm} \times$ $3.3 \mathrm{~cm}$ ) were melted continuously on a melter head that divides the meltwater into three parallel streams. Elemental measurements were made on meltwater from the innermost part of the core with ultra-pure nitric acid added to the melt stream immediately after the melter head; potentially contaminated water from the outer part of the ice is discarded. Elemental analysis of the innermost meltwater stream is performed in parallel on two inductively coupled plasma mass spectrometers (ICPMS), each measuring a different set of elements; some elements were analyzed on both. The dual ICPMS setup allows for measurement of a broad range of 30 elements and data quality control (McConnell et al., 2002, 2007). Precision of the Ca measurements in WD glacial ice is estimated to be $\pm 3 \%$, with a lower detection limit of $0.15 \mathrm{ng} \mathrm{g}^{-1}$. Continuous $\mathrm{Ca}$ and $\mathrm{CH}_{4}$ measurements are done on the same ice, and are exactly co-registered in depth.

\subsection{Firn densification model description}

Air exchange with the overlying atmosphere keeps the interstitial air in the porous firn layer younger than the surrounding ice matrix, resulting in an age difference between polar ice and the gas bubbles it contains, commonly referred to as $\Delta$ age (Schwander and Stauffer, 1984). Here we use a coupled firn-densification-heat-diffusion model to calculate $\Delta$ age back in time (Barnola et al., 1991; Goujon et al., 2003; Schwander et al., 1997; Rasmussen et al., 2013), constrained by measurements of $\delta^{15} \mathrm{~N}$ of $\mathrm{N}_{2}$, a proxy for past firn column thickness (Sowers et al., 1992). The model is based on a dynamical description of the Herron-Langway model formulated in terms of overburden load (Herron and Langway, 1980), which is solved in a Lagrangian reference frame. This model has been applied previously to the Greenland NEEM, NGRIP, and GISP2 cores (Rasmussen et al., 2013; Seierstad et al., 2015; Buizert et al., 2014b), where it gives a good agreement to the Goujon densification model (Rasmussen et al., 2013; Goujon et al., 2003). The model allows for the inclusion of softening of firn in response to impurity loading (Horhold et al., 2012), following the mathematical description of Freitag et al. (2013a). The equations governing the model densification rates are given in Appendix A.

The model uses a 2-year time step and $0.5 \mathrm{~m}$ depth resolution down to $1000 \mathrm{~m}$, the lower model boundary. A thick model domain is needed because of the long thermal memory of the ice sheet. At WD, downward advection of cold surface ice is strong due to the relatively high accumulation rates, and the geothermal gradient does not penetrate the firn column (Cuffey and Paterson, 2010). We further use a lockin density that equals the mean close-off density (Martinerie et al., 1994) minus $17.5 \mathrm{~kg} \mathrm{~m}^{-3}$ (as in Blunier and Schwander, 2000) and an empirical parameterization of lock-in gas age based on firn air measurements from 10 sites (Buizert et al., 2012, 2013).

We furthermore use the steady-state version of the Herron-Langway model (Herron and Langway, 1980) in performing sensitivity studies (Sect. 3.2) and the dynamical Arnaud model (Arnaud et al., 2000; Goujon et al., 2003) to validate our $\Delta$ age solution.

\subsection{Temperature reconstruction and ice-flow model}

Our temperature reconstruction (Fig. 1a) is based on water $\delta \mathrm{D}$, a proxy for local vapor condensation temperature, calibrated using a measured borehole temperature profile (following Cuffey et al., 1995; Cuffey and Clow, 1997) and, for the last $31.2 \mathrm{ka}$, adjusted iteratively to satisfy constraints on firn thickness provided by $\delta^{15} \mathrm{~N}$ and by the observed layer thickness $\lambda(z)$. Using $\delta^{18} \mathrm{O}$ rather than $\delta \mathrm{D}$ in the temperature reconstruction leads to differences that are negligibly small. This borehole temperature calibration approach is possible at WD because the large ice thickness and relatively high accumulation rates help to preserve a memory of past 


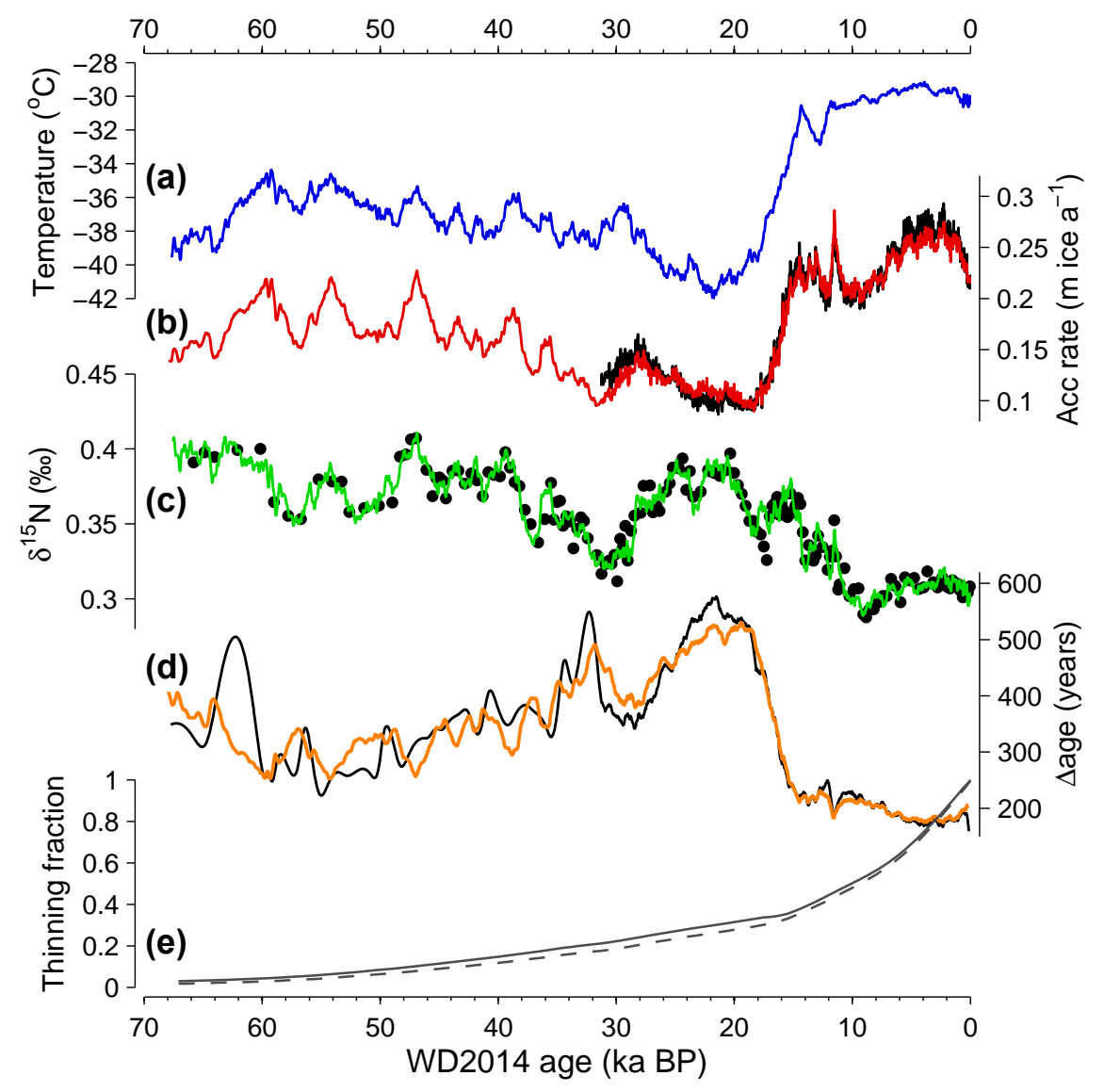

Figure 1. Modeling $\Delta$ age for WAIS Divide. (a) Past temperatures reconstructed from water $\delta \mathrm{D}$, calibrated to the borehole temperature profile. (b) Past accumulation rates as reconstructed by the firn densification inverse model (red), and from the annual-layer count (black). (c) $\delta^{15} \mathrm{~N}$ data (black dots) with densification model output (green). (d) $\Delta$ age calculated using the densification model (orange) and using the Parrenin $\Delta$ depth method (black) with constant $4 \mathrm{~m}$ thick convective zone and no correction for thermal $\delta^{15} \mathrm{~N}$ fractionation. (e) Modeled thinning function from ice-flow model (solid), and a simple Nye strain model for comparison (dashed); the Nye thinning function, which has a uniform strain rate as a function of depth, is given as $f_{\lambda}(z)=(H-z) / H$ with $H$ the ice sheet thickness (Cuffey and Paterson, 2010, p. 616).

temperatures in the ice sheet. A coupled 1-D ice-flow-heatdiffusion model converts surface $T(t)$ into a depth profile for comparison to measured borehole temperatures. The 1D ice-flow model calculates the vertical ice motion, taking into account the surface snow accumulation, the variation in density with depth, and a prescribed history of ice thickness. Vertical motion is calculated by integrating a depth profile of strain rate and adding a rate of basal melt. As in the model of Dansgaard and Johnsen (1969), the strain rate maintains a uniform value between the surface and a depth equal to $80 \%$ of the ice thickness, and then varies linearly to some value at the base of the ice. This basal value is defined by the "basal stretching parameter" $f_{\mathrm{b}}$, the ratio of strain rate at the base to strain rate in the upper $80 \%$ of the ice column. The basal ice is melting, so part of the ice motion likely occurs as sliding. The along-flow gradient in such sliding is unknown and thus so too is the parameter $f_{\mathrm{b}}$. We overcome this problem by making both the current ice thickness and the basal melt rate free parameters when optimizing models with respect to measured borehole temperatures. Because the basal melt rate and $f_{\mathrm{b}}$ affect the vertical velocities in similar fashion, the optimization constrains a combination of melt rate and $f_{\mathrm{b}}$ that is tightly constrained by the measured temperatures. Thus we find that varying $f_{\mathrm{b}}$ through a large range, from 0.1 to 1.5 , changes the reconstructed LGM temperature by less than $0.2^{\circ} \mathrm{C}$. Effects of the prescribed ice-thickness history are likewise minor; assuming a $150 \mathrm{~m}$ thickness increase from the LGM to $15 \mathrm{ka}$ changes the reconstructed LGM temperature by less than $0.2^{\circ} \mathrm{C}$ compared to a constant thickness. Note that the 1-D flow model used here is simpler than the one used by Cuffey and Clow (1997) in that it does not attempt to calculate changes in the shape of the strain rate profile; the unknown basal sliding motion at the WD site negates the usefulness of such an exercise.

One output of the 1-D flow model is the strain history of ice layers as a function of depth and time. The cumulative 


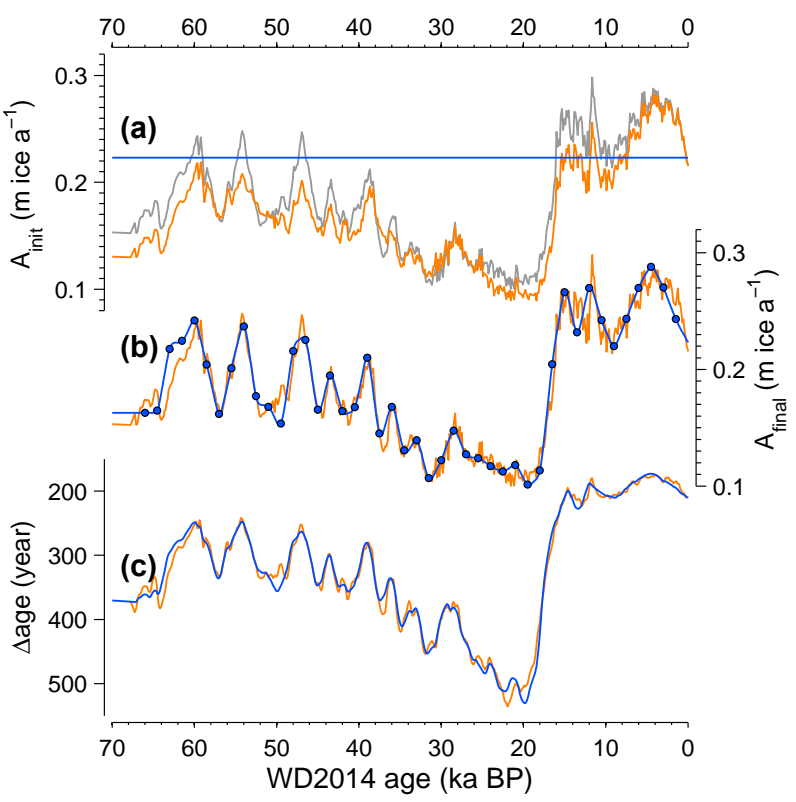

Figure 2. Reconstructing $A(t)$ and $\Delta$ age from $\delta^{15} \mathrm{~N}$ : the choice of accumulation template. (a) $A_{\text {init }}(t)$ based on $\lambda(z)$ from the annuallayer count (0-31.2 ka BP) and Clausius-Clapeyron scaling of water stable isotope data $(34.2-68 \mathrm{ka})$ in orange; $A_{\text {init }}=0.22 \mathrm{ma}^{-1}$ in blue; and for comparison the final $A(t)$ solution (Fig. 1b) in grey. For the orange curve we have used the Nye thinning function (Fig. 1e); the final ice-flow model optimizes the agreement between $A(t)$ obtained from $\lambda(z)$ and from the inverse firn modeling approach. The WD2014 chronology uses the orange $A_{\text {init }}(t)$ scenario. (b) $A(t)$ found in the inverse firn modeling approach using both $A_{\text {init }}(t)$ scenarios; color coding as in panel (a). The function $\xi(t)$ is found as follows. We use control points at 1500-year intervals (blue dots); the algorithm has the freedom to change the value of $\xi(t)$ at each of these points. In between the control points, $\xi(t)$ is found via linear interpolation. (c) Modeled $\Delta$ age using both $A_{\text {init }}(t)$ scenarios; color coding as in panel (a).

strain is represented by the thinning function $f_{\lambda}(z)$ (Cuffey and Paterson, 2010), the ratio of annual-layer thickness at depth in the ice sheet to its original ice-equivalent thickness at the surface when deposited. The modeled thinning function is shown in Fig. 1e (solid line). In the deep part of the ice sheet, $f_{\lambda}(z)$ becomes increasingly uncertain as the unknown basal melt rate and $f_{\mathrm{b}}$ become the dominant controls. Here we optimize the model by comparing accumulation rates derived from $f_{\lambda}(z)$ with those implied by a firn densification model and the measured $\delta^{15} \mathrm{~N}$ of $\mathrm{N}_{2}$ (Sect. 3.1). While this has little effect on the temperature history reconstruction, it provides an important constraint on calculated basal melt rate, an interesting quantity for ice dynamics studies. Our analysis of basal melt rates and further details of the temperature optimization process and 1-D flow modeling will be presented elsewhere.

\section{The gas age-ice age difference ( $\Delta$ age)}

\subsection{The WD2014 $\Delta$ age reconstruction}

The firn densification forward model uses past surface temperature $T(t)$ and accumulation $A(t)$ as model forcings, and provides $\Delta$ age $(t)$ and $\delta^{15} \mathrm{~N}(t)$ as model output.

For the past $31.2 \mathrm{ka}$, WD has an annual-layer-counted chronology; for this period the annual-layer thickness $\lambda(z)$ provides a constraint on past accumulation rates via $\lambda(z)=$ $A(z) \times f_{\lambda}(z)$. WD accumulation reconstructed from $\lambda(z)$ is plotted in black in Fig. 1b.

Prior to $31.2 \mathrm{ka}$ we have no such constraint on $A(t)$, and an alternative approach is needed. We use the densification model as an inverse model, where we ask the model to find the $A(t)$ history that minimizes the root-mean-square (rms) deviation between measured and modeled $\delta^{15} \mathrm{~N}$, given the $T(t)$ forcing. The $\delta^{15} \mathrm{~N}$ data and model fit are shown in Fig. 1c, the $A(t)$ history that optimizes the $\delta^{15} \mathrm{~N}$ fit is shown in Fig. $1 \mathrm{~b}$ (red), and the modeled $\Delta$ age is shown in Fig. 1c (orange). The optimal $A(t)$ history is estimated in two steps. First, we make an initial estimate $A_{\text {init }}(t)$ for the past accumulation history. Second, we adjust the $A(t)$ forcing by applying a smooth perturbation $\xi(t)$ such that $A(t)=[1+\xi(t)] \times A_{\text {init }}(t)$; an automated algorithm is used to find the curve $\xi(t)$ that optimizes the model fit to the $\delta^{15} \mathrm{~N}$ data. For the last $31.2 \mathrm{ka}$ we obtain a good agreement between $A$ obtained from $\lambda(z)$ and the modeled $f_{\lambda}(z)$ (Fig. 1b, black) and $A$ obtained from the inverse method (red). The solution we present here is therefore fully internally consistent, i.e., the $A$ and $T$ histories used in the firn densification modeling are the same as those used in the ice-flow modeling, and they provide a good fit to both the $\delta^{15} \mathrm{~N}$ data and borehole temperature data. WD does not suffer from the $\delta^{15} \mathrm{~N}$ modeldata mismatch that is commonly observed for East Antarctic cores during the glacial period (Landais et al., 2006; Capron et al., 2013).

We base our $A_{\text {init }}$ values on $\lambda(z)$ for the past $31.2 \mathrm{ka}$; prior to that we use the common assumption that $A$ follows $\delta^{18} \mathrm{O}$ (i.e., Clausius-Clapeyron scaling); the fit to the $\delta^{15} \mathrm{~N}$ data is optimized for $A=24.2 \times \exp \left[0.1263 \times \delta^{18} \mathrm{O}\right]$. To test the validity of the Clausius-Clapeyron assumption, we additionally run the scenario $A_{\text {init }}(t)=0.22 \mathrm{ma}^{-1}$ (i.e., constant accumulation at present-day level). The $A(t)$ and $\Delta$ age reconstructed under both $A_{\text {init }}$ scenarios are similar at multimillennial timescales (Fig. 2). In the layer-counted interval $(<31.2 \mathrm{kaBP}), A$ obtained from $\lambda(z)$ and $\delta^{18} \mathrm{O}$ is significantly coherent at all timescales longer than 3000 years, but not at higher frequencies. This is equivalent to the variability resolved in the $A_{\text {init }}(t)=0.22 \mathrm{ma}^{-1}$ scenario above. We conclude that the WD $\delta^{15} \mathrm{~N}$ data support the idea that $A$ follows $\delta^{18} \mathrm{O}$ on multi-millennial timescales. However, there may not be a strong relationship at timescales less than a few thousand years, as is clear from the abrupt $A$ increase around $12 \mathrm{ka}$ seen in $\lambda(z)$ that is not reflected in $\delta^{18} \mathrm{O}$ (Fig. 1a and b). For 
consistency between the upper and deeper part of the core we use the $\Delta$ age values obtained with the inverse densification model for the entire core.

Recently, another $\delta^{15} \mathrm{~N}$-based approach has been suggested that uses $\Delta$ depth, rather than $\Delta$ age, in reconstructing gas chronologies (Parrenin et al., 2012). This method removes the dependence on $T(t)$ and replaces this with a dependence on the thinning function $f_{\lambda}(z)$. Note that this method is very successful in the upper part of an ice core, where $f_{\lambda}(z)$ is well constrained, but not very reliable near the base, where $f_{\lambda}(z)$ is highly uncertain. Therefore, the firn densification modeling approach should be considered to be more reliable at WD during marine isotope stages (MIS) 2 through 4. Results from the $\Delta$ depth method are plotted in black in Fig. 1c, and generally show good agreement with the firn modeling approach. A notable exception is the 60 $65 \mathrm{ka}$ interval, where the $\Delta$ depth method overestimates the $\Delta$ age due to the fact that we have to compress $\lambda(z)$ strongly in order to fit age constraints derived from DO 18 (Sect. 4.5).

Last, we want to point out that the $\delta^{15} \mathrm{~N}$ data support an early warming at WD, as reported recently (WAIS Divide Project Members, 2013). WD $\delta^{15} \mathrm{~N}$ starts to decrease around $20.5 \mathrm{kaBP}$, suggesting a thinning of the firn column. The $\lambda(z)$ (as derived from the layer count) shows that accumulation did not change until $18 \mathrm{kaBP}$, at which point it started to increase (which would act to increase the firn thickness). The most plausible explanation for the $\delta^{15} \mathrm{~N}$ decrease around $20.5 \mathrm{kaBP}$ is therefore an early onset of West Antarctic deglacial warming, in agreement with increasing $\delta^{18} \mathrm{O}$ around that time. The warming enhances the densification rate of polar firn, thereby decreasing its thickness (e.g., Herron and Langway, 1980).

\section{2 $\Delta$ age sensitivity study}

Besides $A$ and $T$ there are several model parameters that have the potential to influence the model outcome; these are the convective zone (CZ) thickness (Sowers et al., 1992; Kawamura et al., 2006), surface density $\left(\rho_{0}\right)$, and sensitivity to ice impurity content. In this section we evaluate the sensitivity of the model output to all of these parameters. We performed 1000 model runs in which the model parameters were randomly perturbed. The spread in $\Delta$ age model results is used to calculate the WD2014 age uncertainty.

Convective zone thickness. In the WD2014 model run (Sect. 3.1) we use a constant $3.5 \mathrm{~m} \mathrm{CZ}$, corresponding to the present-day situation (Battle et al., 2011). In the sensitivity study we vary the CZ by one of two methods: (1) we let the $\mathrm{CZ}$ be constant in time; its thickness is set by drawing from a Gaussian distribution with $3.5 \mathrm{~m}$ mean and $3.5 \mathrm{~m} 2 \sigma$ width (i.e., $95 \%$ probability of drawing a value in the $0-7 \mathrm{~m}$ range). (2) We let the $\mathrm{CZ}$ be a function of accumulation rate (Dreyfus et al., 2010), $\mathrm{CZ}=3.5+k \times(A-0.22)$; we draw $k$ from a Gaussian distribution with mean of -10 and a $2 \sigma$ width of 40 (at an LGM $A$ of $10 \mathrm{~cm} \mathrm{a}^{-1}$ this gives a CZ of $0-10 \mathrm{~m}$ thickness). In both methods, whenever $\mathrm{CZ}$ values are selected that are smaller than $0 \mathrm{~m}$, the CZ thickness is set to $0 \mathrm{~m}$ instead. For each of the 1000 model runs in the sensitivity study we randomly selected either of the two methods.

Surface density. In the WD2014 model run we use past surface densities $\left(\rho_{0}\right)$ as given by the parameterization of Kaspers et al. (2004). In the sensitivity study we add a constant offset to the Kaspers values, the magnitude of which is drawn from a Gaussian distribution of zero mean and a $2 \sigma$ width of $60 \mathrm{~kg} \mathrm{~m}^{-3}$. This range corresponds to the full range of observed $\rho_{0}$ variability in Kaspers et al. (2004).

Past temperatures. Model temperature forcing is constrained by $\delta \mathrm{D}$ and measured borehole temperatures. There is, however, a range to the solutions allowed by the borehole temperature and ice-flow model; here we use the upper and lower extremes of this range, determined by Monte Carlo analysis using uncertainties of input variables. The scenarios were chosen to provide the maximum $T$ range for the glacial period rather than for the Holocene, because we are interested in the uncertainty in the methane synchronization (68-31.2 kaBP). In the sensitivity study we use $T(t)=$ $T_{\text {optimal }}(t)+\kappa \times \Delta T(t)$, where $T_{\text {optimal }}$ is the forcing used in the WD2014 model run (Fig. 1a), $\Delta T(t)$ is half the difference between the maximum- $T$ and minimum- $T$ scenarios, and $\kappa$ is drawn from a Gaussian distribution of zero mean and unit $2 \sigma$ width (giving $95 \%$ probability that $T(t)$ is within the extreme range identified from the borehole, Fig. 3a).

$\delta^{15} \mathrm{~N}$ uncertainty. We conservatively adopt an analytical uncertainty of $0.005 \%$ o for this data set; in addition, the interpretation of $\delta^{15} \mathrm{~N}$ in terms of firn thickness is subject to further uncertainty due to irregular firn layering and the stochastic nature of bubble trapping, as was observed for other atmospheric gases such as $\mathrm{CH}_{4}$ (Etheridge et al., 1992; Rhodes et al., 2013). For each run of the sensitivity study, we therefore perturb each of the individual $\delta^{15} \mathrm{~N}$ data points by adding an offset that is drawn from a Gaussian distribution of zero mean and a $2 \sigma$ width of $0.015 \%$.

Impurity-enhanced densification. Following recent work we include the possibility that increased glacial impurity loading could have enhanced densification rates (Horhold et al., 2012; Freitag et al., 2013a). We use the mathematical formulation of Freitag et al. (2013a), in which the activation energy of the sintering process is a function of the $\mathrm{Ca}$ concentration in the firn. The value of $\beta$, the sensitivity to $\mathrm{Ca}$, is drawn from a Gaussian distribution with 0.0015 mean and a $2 \sigma$ width of 0.0015 . The topic of impurity-enhanced densification is discussed in detail in Sect. 3.3.

The $A$ and $\Delta$ age scenarios found in the sensitivity study are shown in Fig. $3 \mathrm{~b}$ and c, respectively. The shaded areas in Fig. $3 \mathrm{~b}$ and $\mathrm{c}$ give the total range of solutions, as well as the $\pm 2 \sigma$ and $\pm 1 \sigma$ confidence intervals. Note that the total range of solutions will depend on the number of model runs (here 1000 ) but that the position of the $\pm 2 \sigma$ and $\pm 1 \sigma$ envelopes will not. To investigate the distribution of values, we include 

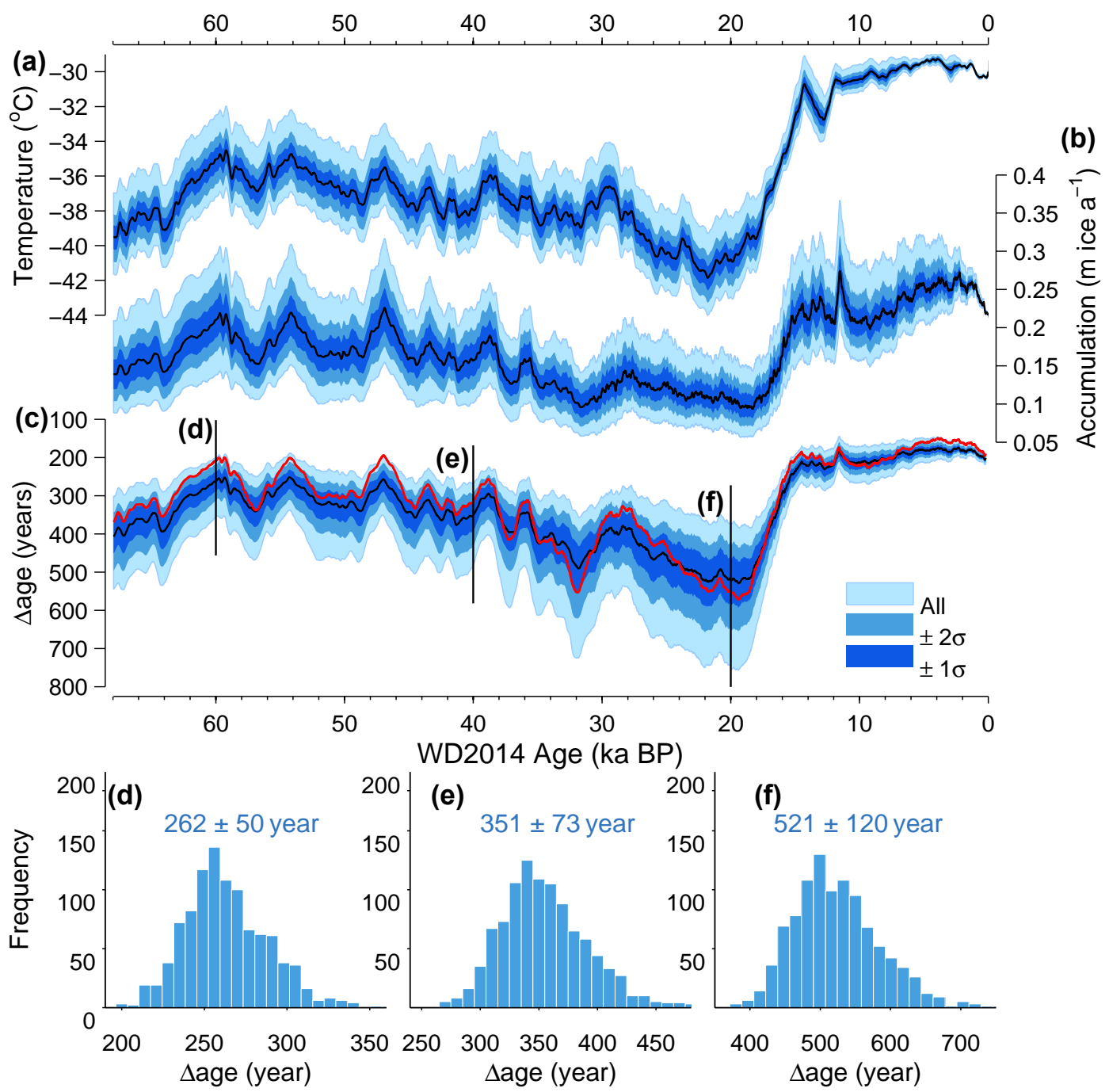

Figure 3. $\Delta$ age sensitivity study. Shades of blue give the confidence intervals as marked; the black curves represent the values used in the WD2014 chronology; the red curve gives an alternative $\Delta$ age solution using the Arnaud densification model. (a) Temperature forcing of the densification model. (b) Reconstructed accumulation rates. (c) Reconstructed $\Delta$ age; note the reversed scale. Histograms of $\Delta$ age distribution are shown for (d) $60 \mathrm{kaBP}$, (e) $40 \mathrm{kaBP}$, and (f) $20 \mathrm{kaBP}$. Distribution mean and $2 \sigma$ uncertainty bound is stated in each panel.

histograms of $\Delta$ age at $20 \mathrm{kyr}$ intervals (Fig. 3d-f). Based on the sensitivity study, we estimate the WD $\Delta$ age to be $521 \pm 120$ years ( $2 \sigma$ uncertainty) at the LGM $(\sim 20 \mathrm{kaBP})$. The $\Delta$ age value of $351 \pm 73$ years at $40 \mathrm{kaBP}$ gives a representative $\Delta$ age for MIS $3 ; \Delta$ age at $60 \mathrm{kaBP}$ is $262 \pm 50$ years.

Additionally, we have repeated our $\Delta$ age reconstruction using the firn densification physics described by Arnaud et al. (2000) rather than the Herron-Langway description used so far; the Arnaud model provides the physical basis for the commonly used firn densification model of Goujon et al. (2003). More details on the implementation of the Arnaud model are given in Appendix A. $\Delta$ age found using the Arnaud model is plotted in red in Fig. 3c. Averaged over the entire core, $\Delta$ age found with the Arnaud model is 19 years (about $7 \%$ ) smaller than $\Delta$ age from the Herron-Langway model. The root-mean-square (rms) difference between both solutions is 35 years, corresponding to 0.63 times the $2 \sigma$ uncertainty found in the sensitivity study. Both solutions are thus found to be in good agreement. The Herron-Langway approach is preferred because the internally consistent solution of temperature, accumulation, and ice flow associated with it is in better agreement with borehole temperature data than the solutions associated with the Arnaud model. Furthermore, the Herron-Langway model is more successful in simulating the magnitude of the $\delta^{15} \mathrm{~N}$ response to the accumulation anomaly at $12 \mathrm{ka}$ (not shown), suggesting it has a more realistic sensitivity to accumulation variability. 

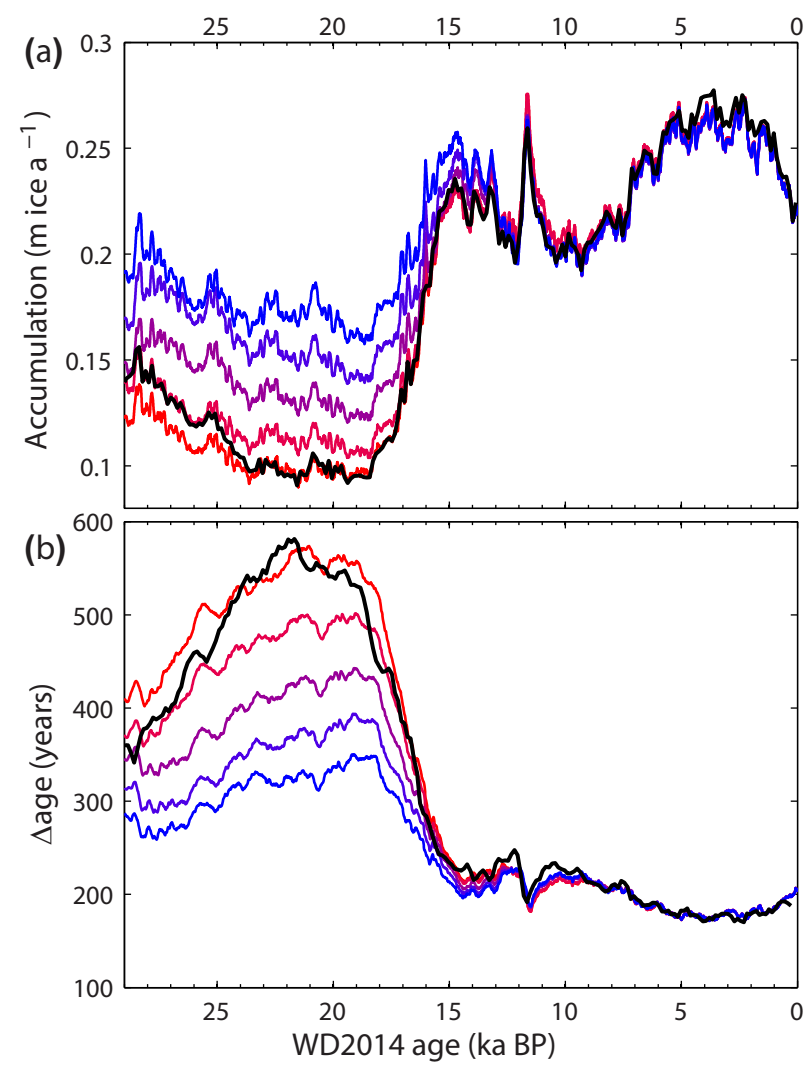

Figure 4. Impurity enhancement of densification rates at WD. Densification modeling results for (a) accumulation rates and (b) $\Delta$ age. We use Ca sensitivities $\beta=0$ (red) through $\beta=1 \times 10^{-2}$ (blue), in steps of $2.5 \times 10^{-3}$ (shades of deep purple). Black curves give $A$ and $\Delta$ age from ice-flow modeling and $\lambda(z)$.

\subsection{Impurity softening of firn?}

Recent work suggests a link between densification rates and impurity content (for which $\left[\mathrm{Ca}^{2+}\right]$ is used as a proxy) in polar firn (Horhold et al., 2012; Freitag et al., 2013a). Here we measured total $[\mathrm{Ca}]$ by ICP-MS, but at WD nearly all $\mathrm{Ca}$ is in the form of $\mathrm{Ca}^{2+}$. The influence of the impurity sensitivity $\beta$ (see Eq. A6 in the Appendix) on $\Delta$ age at WD is shown in Fig. 4 . The sensitivity recommended by Freitag et al. (2013a) from investigating present-day firn packs is $\beta=1 \times 10^{-2}$. We reconstructed $A$ and $\Delta$ age with the firn densification inverse model using five values of $\beta$ ranging from $\beta=0$ (red) to $\beta=1 \times 10^{-2}$ (blue) in steps of $2.5 \times 10^{-3}$. Average [Ca] is around $0.8 \mathrm{ng} \mathrm{g}^{-1}$ in the early Holocene and around $9 \mathrm{ng} \mathrm{g}^{-1}$ in the LGM; a change to about an order of magnitude. Following Freitag et al. (2013a) we use the total [Ca] rather than non-sea-salt $\mathrm{Ca}$. If densification rates are sensitive to impurity loading (large $\beta$, blue curves), this results in increased firn compaction during the LGM. The densification model, which is trying to match the $\delta^{15} \mathrm{~N}$ data, will compensate by increasing the $A$ forcing, which in turn results in a decreas- ing $\Delta$ age. Hence the model simulations with large $\beta$ (blue) give a higher $A$ and smaller $\Delta$ age.

For the past $31.2 \mathrm{ka}$ we have an independent $A$ estimate from $\lambda(z)$ that we can compare to the solutions from the firn model (Fig. 4, black curve). We also plotted $\Delta$ age reconstructed via the $\Delta$ depth method of Parrenin et al. (2012). Remarkably, we find consistent solutions only when using a Ca sensitivity $\beta \leq 2.5 \times 10^{-3}$, i.e., less than one-quarter of the sensitivity suggested by Freitag et al. (2013a). The best fit to the independent LGM (25-20 kaBP) $A$ and $\Delta$ age estimates is obtained for $\beta=0$. We conclude that WD does not provide any evidence for impurity (or, more specifically, Ca) enhancement of densification rates.

An important caveat is that our model uses 10-yearaverage [Ca] values, and therefore cannot resolve effects of interannual layering within the firn. Explicitly modeling the layering would require centimeter-scale resolution in the dynamical firn model, which is prohibitive from a computational point of view. Furthermore, $[\mathrm{Ca}]$ data at the required sub-annual resolution are difficult, if not impossible, to measure for the deepest part of the core, where $\lambda(z)$ is below $1 \mathrm{~cm} \mathrm{a}^{-1}$. Increased firn layering and enhanced bulk densification affect the firn thickness in a similar manner; both lead to a shallower lock-in depth, and thereby a reduced $\delta^{15} \mathrm{~N}$. Therefore, in order to reconcile our WD results with the impurity hypothesis of Horhold et al. (2012), one would need to invoke a strong reduction in LGM firn layering relative to the present day to compensate for the impurity-driven increase in bulk densification rates. Recent work on the EDML core suggests that firn density layering may have been more pronounced during glacial times (Bendel et al., 2013); including firn layering is therefore likely to only exacerbate the problem.

Work on present-day firn has provided support for firn softening by impurity loading (Horhold et al., 2012; Freitag et al., 2013a, b). More work is needed to understand how densification rates are linked to impurity content in a mechanistic, rather than purely empirical, way. Perhaps such a microscopic description could provide an explanation why firn densification rates at WD, to first order, do not appear to be affected by order-of-magnitude variations in [Ca] loading. One possible explanation could be that densification rates are controlled by some parameter that co-varies with $\mathrm{Ca}$ in modern day firn yet does not change appreciably over glacial cycles (Fujita et al., 2014).

\section{Constructing the WAIS Divide WD2014 chronology}

\subsection{Annual layer count (0-31.2 ka)}

A first layer-counted chronology for the upper $2800 \mathrm{~m}$ of the WD core based on electrical conductivity measurements (ECM), named WDC06A-7, was presented by WAIS Divide Project Members (2013). The WAIS chronology presented 


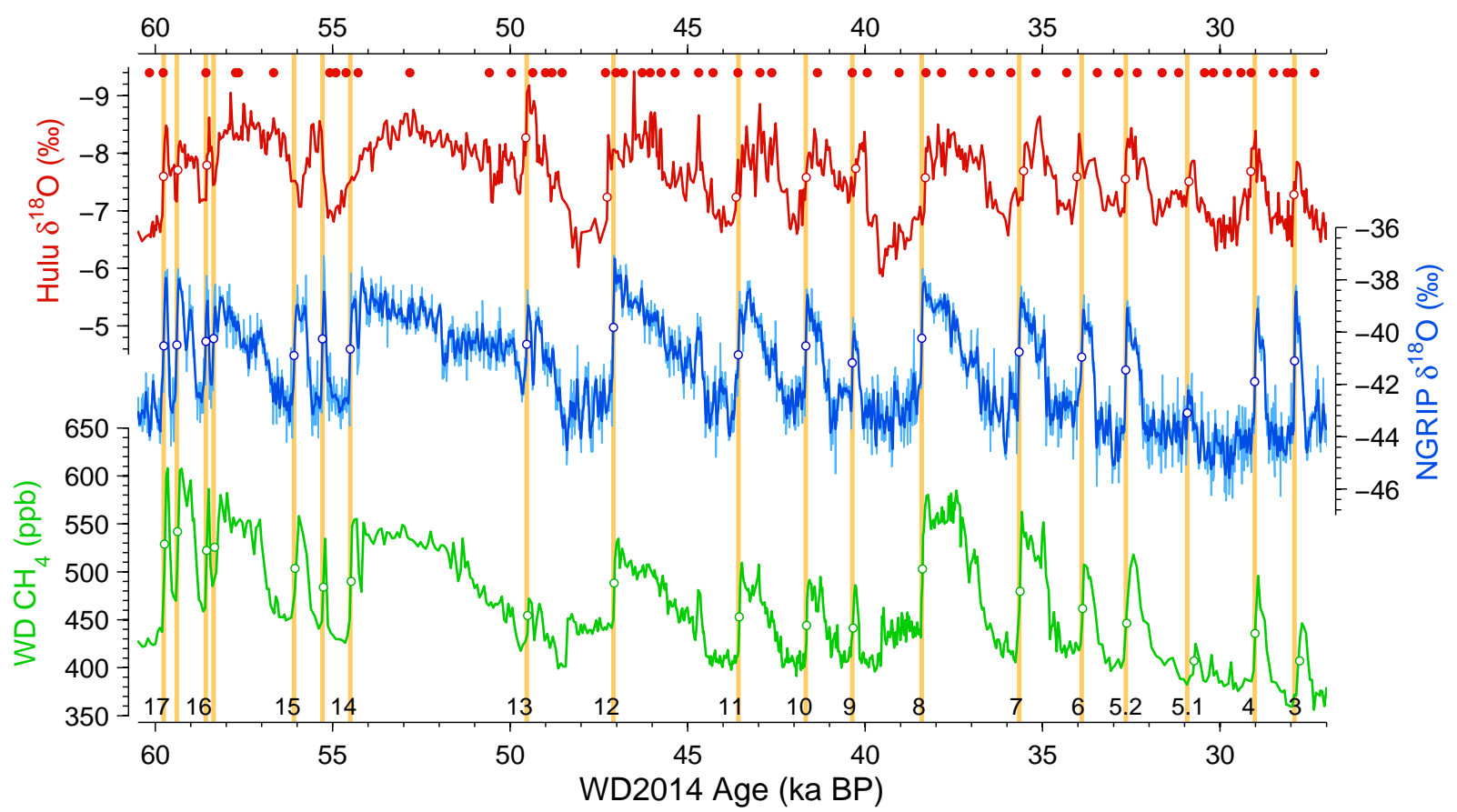

Figure 5. Records of abrupt DO climate variability, (a) revised Hulu Cave speleothem $\delta^{18} \mathrm{O}$ record on Hulu chronology with U / Th ages above the time series (red dots), (b) NGRIP ice core $\delta^{18} \mathrm{O}$ on $1.0063 \times$ GICC05 chronology, and (c) WD $\mathrm{CH}_{4}$ on WD2014 (discrete data). DO numbering is given in the bottom of the figure following Rasmussen et al. (2014). White dots denote the midpoints of the stadial-interstadial transitions; the orange vertical lines show the timing of the NGRIP tie points (on $1.0063 \times$ GICC05). For DO 3, 4, and 5.1 the WD2014 chronology is based on annual-layer counting, and minor timing differences exist between WD and NGRIP.

in this work, WD2014, uses an updated layer count for the upper $2850 \mathrm{~m}$, based on new data and analyses that have become available since publication of WDC06A-7. These updates are as follows:

1. a reassessment of the dating in the upper $577 \mathrm{~m} \mathrm{(2.4 \textrm {ka } )}$ using high-resolution multi-parameter chemistry data in combination with automated layer detection algorithms (Winstrup et al., 2012);

2. a reassessment of the dating between 577 and $2300 \mathrm{~m}$ (2.4-15.3 ka) using high-resolution multi-parameter chemistry data in combination with ECM;

3. a reassessment of the dating between 2300 and $2800 \mathrm{~m}$ (15.3-29.5 ka) using ECM and dust particle measurements, with the ECM having increasing importance with depth;

4. an extension of the annual-layer dating between 2800 and $2850 \mathrm{~m}$ (29.5-31.2 ka) using ECM.

Details on the updated WD layer count and the layer counting methodology are presented in part 2 of the WD2014 papers.

\subsection{Methane synchronization $(31.2-68 \mathrm{ka})$}

For the deep part of the core where an annual-layer count is not available, we date WD by synchronization to well- dated Northern Hemisphere (NH) climate records of abrupt DO variability using the WD record of globally well-mixed $\mathrm{CH}_{4}$ (Fig. 5). This process consists of several steps:

1. Determine the midpoint of the abrupt DO transitions in WD $\mathrm{CH}_{4}$, NGRIP $\delta^{18} \mathrm{O}$, and Hulu speleothem $\delta^{18} \mathrm{O}$.

2. Assign a gas age to the $\mathrm{WD} \mathrm{CH}_{4}$ tie points (i.e., the DO transitions).

3. Apply the WD $\Delta$ age (Sect. 3) to find the corresponding ice age at the depth of the $\mathrm{CH}_{4}$ tie points.

4. Interpolate between the ice age constraints to find the WD depth-age relationship.

5. Redo the $\Delta$ age calculations on the new ice age scale.

6. Repeat steps 3-5 iteratively until the depth-age relationship is stable within 1 year. At WD this happened after three iterations.

These steps are described in more detail in the following sections.

\subsection{Establishing the midpoint in abrupt DO transitions}

The procedure for determining the midpoint of the abrupt DO warming transitions is depicted in Fig. 6. For each of 


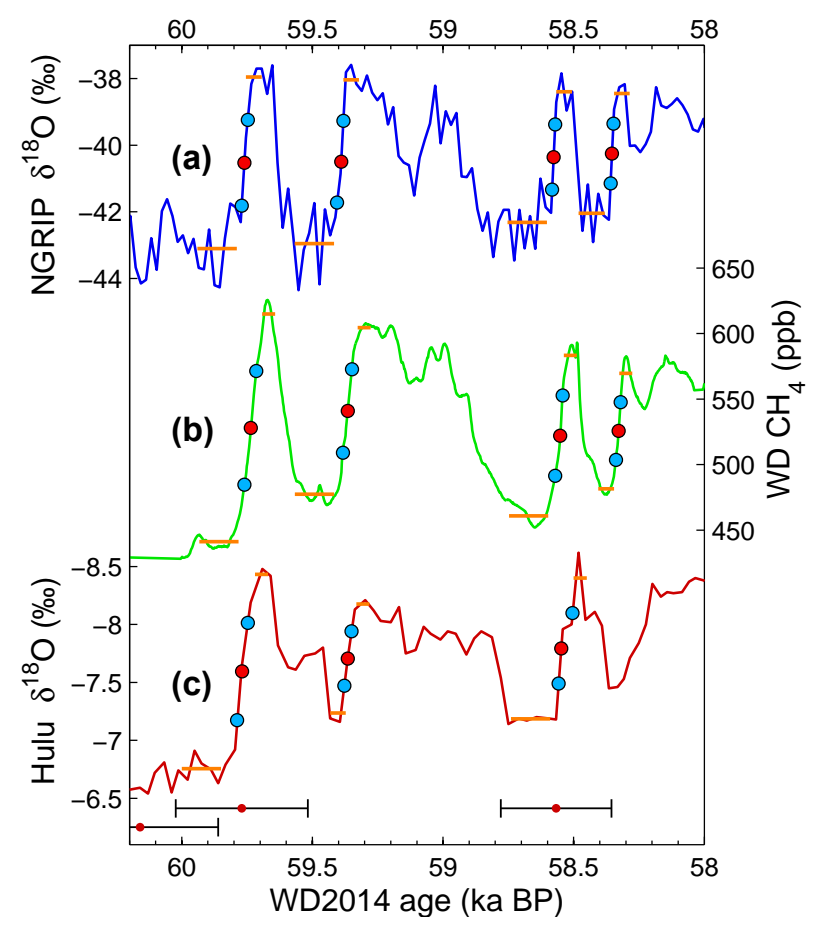

Figure 6. Determining the midpoint for the abrupt warming phases of (from oldest to youngest) DO 17.2, 17.1, 16.2, and 16.1 in (a) NGRIP $\delta^{18} \mathrm{O}$ (on $1.0063 \times$ GICC05), (b) $\mathrm{WD} \mathrm{CH}_{4}$ (continuous data, on WD2014), and (c) Hulu $\delta^{18} \mathrm{O}$ with $\mathrm{U} / \mathrm{Th}$ ages beneath the time series (red dots with error bars). Red dots give the midpoint (50\%) of the DO transition; the blue dots give the 25 and $75 \%$ marks in the DO transitions. The DO transition at $58.35 \mathrm{ka}$ was not used in Hulu, where it is much more gradual than in the other records (possibly because calcite sampling was not perfectly perpendicular to the stalagmite isochrones, or because growth rates were variable in between the U / Th ages).

the transitions we manually determine pre-event and postevent averages, as indicated by the orange lines. The averaging time is set to 150 and 50 years for stadial and interstadial periods, respectively; this difference in duration is used because (i) several of the interstadials are of short duration and (ii) Greenland $\delta^{18} \mathrm{O}$ is more variable during stadial climates, requiring longer averaging. For DO 16.1, the duration of the pre-event stadial baseline climate was shorter than 150 years, and the averaging time was reduced to 100 years (Fig. 6).

After determining the pre- and post-event averages, we use linear interpolation of the time series to find the time at which the variable of interest had completed 25,50 , and $75 \%$ of the total transition (Fig. 6). We use the $50 \%$ marker (red) as the midpoint of the transition, which is used in the methane synchronization. The 25 and $75 \%$ markers (blue) are used as the $\pm 1 \sigma$ uncertainty estimate. In rare cases the time series contain inversions within the transitions that lead to ambiguity in the timing of the markers; for these events we find the markers using a monotonic spline fit to the data.
The midpoints of abrupt interstadial terminations were determined in the same fashion (WD $\mathrm{CH}_{4}$ and NGRIP only). Tables 1 and 2 give the results for $\mathrm{NH}$ warming and $\mathrm{NH}$ cooling, respectively.

\subsection{Synchronizing WD to a NGRIP-Hulu hybrid chronology}

Abrupt DO variability is expressed clearly in a great number of NH climate records (Voelker, 2002). For the purpose of methane synchronization, our interest is in highresolution records that express the abrupt DO events very clearly, and are furthermore exceptionally well dated. We here use a combination of two such NH records (Fig. 5), namely the Greenland NGRIP $\delta^{18} \mathrm{O}$ record (NGRIP community members, 2004), and a refined version of the Hulu Cave speleothem $\delta^{18} \mathrm{O}$ record (Edwards et al., 2015; Reimer et al., 2013; Southon et al., 2012) with improved resolution and additional dating constraints (see Wang et al., 2001, for the original, lower resolution Hulu $\delta^{18} \mathrm{O}$ record). The DO events are resolved most clearly in the NGRIP $\delta^{18} \mathrm{O}$ record, which is available at 20-year resolution. We use the GICC05modelext chronology for this core, which is based on annuallayer counting back to $60 \mathrm{kaBP}$ and ice-flow modeling for ice older than $60 \mathrm{ka}$ (Rasmussen et al., 2006; Svensson et al., 2006; Wolff et al., 2010). While annual-layer counting provides accurate relative ages (e.g., the duration of DO interstadials), it provides relatively inaccurate absolute ages due to the cumulative nature of counting uncertainty (Table 1). The refined Hulu $\delta^{18} \mathrm{O}$ record also shows the abrupt DO events in high temporal resolution (Fig. 6). The speleothem chronology is based on $\mathrm{U} / \mathrm{Th}$ radiometric dating, providing much smaller uncertainty in the absolute ages than GICC05 (Table 1). The reason for selecting this record over other speleothem records is the large number of $U / T h$ dates, the low detrital Th at the site, and the high sampling resolution of the $\delta^{18} \mathrm{O}$ record (Wang et al., 2001). In the Hulu data, as in other records of DO variability, the interstadial onsets are more pronounced and abrupt than their terminations. We therefore only use the timing of the former as age constraints, as they can be established more reliably. The onset of $\mathrm{NH}$ interstadial periods as expressed in Hulu $\delta^{18} \mathrm{O}$ is given in Table 1 .

In both the NGRIP and Hulu Cave $\delta^{18} \mathrm{O}$ records we have determined the ages of the midpoints of the DO transitions (Fig. 6; Table 1); a plot of their difference (Hulu age minus NGRIP age) is shown in Fig. 7, where the error bars denote the root sum square of the NGRIP and Hulu midpoint determination uncertainty (Sect. 4.3). The Hulu ages are systematically older than the NGRIP ages, and the age difference increases going further back in time. Note that the Hulu-NGRIP age difference is smaller than the stated GICC05 counting uncertainty (832 to 2573 years) but larger than the Hulu age uncertainty ( 92 to 366 years). A linear fit through these data, forced to intersect the origin, is given by 
Table 1. Overview of $\mathrm{CH}_{4}$ tie points for $\mathrm{NH}$ warming events. WD ages printed in boldface are assigned as part of the $\mathrm{CH}_{4}$ synchronization; all other ages are on their independent chronologies.

\begin{tabular}{|c|c|c|c|c|c|c|c|c|c|c|c|}
\hline & \multicolumn{4}{|c|}{ NGRIP } & \multicolumn{3}{|c|}{ Hulu } & \multicolumn{4}{|c|}{ WD } \\
\hline & $\begin{array}{r}\text { Depth } \\
(\mathrm{m})\end{array}$ & $\begin{array}{r}\text { Age } \\
(\text { years BP) }\end{array}$ & $\begin{array}{l}\text { Age uncert. } \\
\text { (years) }\end{array}$ & $\begin{array}{r}\text { Midpoint } \\
\text { (years) }\end{array}$ & $\begin{array}{r}\text { Hulu age } \\
\text { (years BP) }\end{array}$ & $\begin{array}{r}\text { Age uncert. } \\
\text { (years) }\end{array}$ & $\begin{array}{r}\text { Midpoint } \\
\text { (years) }\end{array}$ & $\begin{array}{r}\text { Depth } \\
(\mathrm{m})\end{array}$ & $\begin{array}{r}\text { Gas age } \\
(\text { years BP) }\end{array}$ & $\begin{array}{r}\text { Ice age } \\
\text { (years BP) }\end{array}$ & $\begin{array}{r}\text { Midpoint } \\
\text { (years) }\end{array}$ \\
\hline YD-PB & 1490.89 & 11619 & 98 & 23 & & & & 1983.02 & 11546 & 11740 & 33 \\
\hline OD-BA & 1604.05 & 14628 & 185 & 15 & & & & 2259.40 & 14576 & 14804 & 29 \\
\hline DO 3 & 1869.00 & 27728 & 832 & 12 & 27922 & 95 & 39 & 2755.74 & 27755 & 28144 & 19 \\
\hline DO 4 & 1891.27 & 28838 & 898 & 14 & 29134 & 92 & 21 & 2797.92 & 29011 & 29397 & 22 \\
\hline DO 5.1 & 1919.48 & 30731 & 1023 & 11 & 30876 & 255 & 37 & 2848.38 & 30730 & 31186 & 22 \\
\hline DO 5.2 & 1951.66 & 32452 & 1132 & 15 & 32667 & 236 & 21 & 2885.44 & 32631 & 33051 & 17 \\
\hline DO 6 & 1974.48 & 33687 & 1213 & 19 & 34034 & 337 & 36 & 2913.01 & 33874 & 34283 & 18 \\
\hline DO 7 & 2009.62 & 35437 & 1321 & 16 & 35532 & 299 & 20 & 2958.64 & 35636 & 35982 & 20 \\
\hline DO 8 & 2069.88 & 38165 & 1449 & 13 & 38307 & 155 & 19 & 3021.37 & 38381 & 38681 & 33 \\
\hline DO 9 & 2099.50 & 40104 & 1580 & 13 & 40264 & 241 & 42 & 3066.52 & 40332 & 40690 & 19 \\
\hline DO 10 & 2123.98 & 41408 & 1633 & 14 & 41664 & 310 & 27 & 3094.17 & 41643 & 41980 & 18 \\
\hline DO 11 & 2157.58 & 43297 & 1736 & 17 & 43634 & 144 & 26 & 3130.44 & 43544 & 43866 & 15 \\
\hline DO 12 & 2221.96 & 46794 & 1912 & 21 & 47264 & 153 & 20 & 3195.25 & 47064 & 47335 & 16 \\
\hline DO 13 & 2256.73 & 49221 & 2031 & 17 & 49562 & 251 & 52 & 3237.65 & 49506 & 49836 & 19 \\
\hline DO 14 & 2345.39 & 54164 & 2301 & 11 & & & & 3311.09 & 54480 & 54747 & 13 \\
\hline DO 15.1 & 2355.17 & 54940 & 2349 & 16 & & & & 3322.24 & 55261 & 55564 & 11 \\
\hline DO 15.2 & 2366.15 & 55737 & 2392 & 26 & & & & 3329.72 & 56063 & 56381 & 14 \\
\hline DO 16.1 & 2398.71 & 57988 & 2498 & 11 & & & & 3350.44 & 58328 & 58610 & 9 \\
\hline DO 16.2 & 2402.25 & 58210 & 2510 & 12 & 58545 & 226 & 22 & 3352.59 & 58552 & 58848 & 14 \\
\hline DO 17.1 & 2414.82 & 59018 & 2557 & 15 & 59364 & 366 & 18 & 3360.02 & 59364 & 59627 & 17 \\
\hline DO 17.2 & 2420.35 & 59386 & 2573 & 15 & 59772 & 254 & 23 & 3363.42 & $\mathbf{5 9 7 3 5}$ & 59997 & 25 \\
\hline DO 18 & 2465.84 & 64049 & 2611 & 30 & & & & 3388.73 & 64428 & 64773 & 15 \\
\hline
\end{tabular}

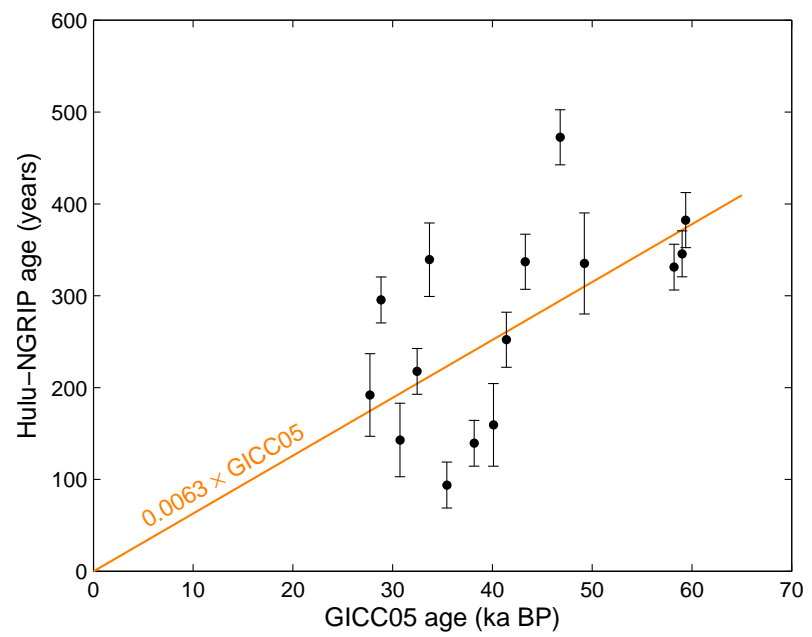

Figure 7. Hulu-NGRIP age offset at the midpoint of the DO $\delta^{18} \mathrm{O}$ transitions. The error bars denote the root sum square of the midpoint determination uncertainty in NGRIP and Hulu $\delta^{18} \mathrm{O}$ (Table 1). The GICC05 ages are placed on the BP 1950 scale rather than the b2k scale (years prior to $2000 \mathrm{CE}$ ).

$0.0063 \times$ GICC05 age, suggesting that the GICC05 annuallayer count on average misses 6.3 out of every 1000 layers. Because of this observation we use a linearly scaled version of the GICC05 chronology (GICC05 × 1.0063) as the target chronology for methane synchronization. This approach has several advantages. First, it respects both the superior relative ages (i.e., interval durations) of GICC05, as well as the superior absolute ages of the Hulu chronology. Second, it is very simple to convert between the WD2014 and GICC05 chronologies $\left(\mathrm{CH}_{4}\right.$-synchronized section of the chronology only); one simply needs to divide WD2014 ages by 1.0063 (and add 50 years to convert to the b2k reference date). Third, it still allows for direct synchronization of WD $\mathrm{CH}_{4}$ to the NGRIP $\delta^{18} \mathrm{O}$ record, providing more tie points than direct synchronization to the Hulu record would. Note that the GICC05 $\times 1.0063$ target chronology respects the Hulu age constraints in an average sense only; the age of individual events differs between Hulu and our target chronology by up to 180 years. Our approach therefore represents only a firstorder correction of a growing offset between GICC05 and Hulu; nonlinear temporal changes in the counted dating error may exist from one tie point to the next (Fleitmann et al., 2009).

The exercise of finding the transition midpoints and determining the GICC05-Hulu scaling factor was performed by two of the authors (J. P. Severinghaus and C. Buizert), independently of each other. The scaling factors obtained were 1.0063 and 1.0064, respectively, showing that, to first order, this result is insensitive to (subjective) judgment in identifying the transitions. The difference between the Hulu ages and $1.0063 \times$ GICC05 ages are all within the stated Hulu $2 \sigma$ dating error (Table 1). Consequently, our chronology is not in violation of any Hulu constraint as it respects the Hulu $2 \sigma$ error at all of the tie points. In deriving the scaling we have assumed that the abrupt DO transitions observed in NGRIP and Hulu are simultaneous, which is not necessarily true. The 
variations in monsoon intensity represented by Hulu $\delta^{18} \mathrm{O}$ are commonly explained by meridional movement of the Intertropical Convergence Zone (ITCZ) and tropical rainfall belts (Wang et al., 2001, 2006; Kanner et al., 2012); modeling work suggests such atmospheric readjustments occur on decadal timescales in response to $\mathrm{NH}$ high-latitude forcing (Chiang and Bitz, 2005; Broccoli et al., 2006; Cvijanovic and Chiang, 2013). Moreover, $\mathrm{CH}_{4}$ emission changes are nearsynchronous with Greenland $\delta^{18} \mathrm{O}$ variations, which they lag by only a few decades on average (Huber et al., 2006; Baumgartner et al., 2014; Rosen et al., 2014). Since both $\mathrm{CH}_{4}$ emissions and Hulu $\delta^{18} \mathrm{O}$ are closely linked to tropical hydrology, timing lags between NGRIP and Hulu are also expected to be on decadal timescales. The uncertainty in the NGRIP-Hulu phasing is therefore probably small (decadal) relative to the correction we apply (up to 400 years).

Rather than synchronizing WD $\mathrm{CH}_{4}$ to Greenland $\mathrm{CH}_{4}$ records, we have chosen to synchronize directly to NGRIP $\delta^{18} \mathrm{O}$, which varies in phase with $\mathrm{CH}_{4}$ (but with a nearly constant time lag). We let the midpoint in the $\mathrm{CH}_{4}$ transitions lag the midpoint in the NGRIP $\delta^{18} \mathrm{O}$ transition by 25 years, as suggested by studies of Greenland $\delta^{15} \mathrm{~N}^{-} \mathrm{CH}_{4}$ phasing (Huber et al., 2006; Baumgartner et al., 2014; Rasmussen et al., 2013; Kindler et al., 2014; Rosen et al., 2014). The rationale behind this approach is threefold. First, throughout MIS 3 the NGRIP $\delta^{18} \mathrm{O}$ record has both better precision and higher temporal resolution than any available Greenland $\mathrm{CH}_{4}$ record (Baumgartner et al., 2014; Brook et al., 1996; Blunier et al., 2007). Second, the dating of Greenland gas records depends on the highly variable $\Delta$ age function, which is not equally well constrained for all DO events (Schwander et al., 1997; Rasmussen et al., 2013). This reliance on Greenland $\Delta$ age would introduce an additional source of uncertainty. The NGRIP $\delta^{18} \mathrm{O}$ record, on the other hand, is accurately dated through the GICC05 layer count. Third, Greenland $\mathrm{CH}_{4}$ records are more strongly impacted by firn smoothing than the $\mathrm{WD} \mathrm{CH}_{4}$ record, because glacial accumulation is lower in Greenland (Greenland glacial $\Delta$ age is about 2-3 times as high as WD $\Delta$ age during that time). In summary, our approach circumvents the uncertainties associated with using Greenland $\mathrm{CH}_{4}$ as an intermediary, or, to state this another way, the uncertainty in the phasing between $\mathrm{CH}_{4}$ and Greenland $\delta^{18} \mathrm{O}$ is smaller than the uncertainty in the Greenland $\Delta$ age.

\subsection{Interpolation between age constraints}

We can assign a gas age to each of the depths where an abrupt WD $\mathrm{CH}_{4}$ transitions occurs; we do this for DO 4.1 through DO 18, i.e., the events prior to $31.2 \mathrm{kaBP}$ (the onset of the WD layer count). The gas age we assign is equal to 1.0063 times the GICC05 age for the same event, with 25 years subtracted to account for the slight $\mathrm{CH}_{4}$ lag behind Greenland $\delta^{18} \mathrm{O}$. By adding $\Delta$ age (Sect. 3 ) to this gas age we assign an ice age. These assigned ages are printed in boldface in Tables 1 and 2 .

To obtain a continuous depth-age relationship between these ice age constraints, we have to apply an interpolation strategy. This task amounts to estimating the annual-layer thickness $\lambda(z)$ along the deep part of the core. The simplest approach is to assume a constant accumulation rate in between the age constraints; this is shown in Fig. $8 \mathrm{~b}$ for the case where we use the age constraints from $\mathrm{NH}$ warming events only (black) or the age constraints from both $\mathrm{NH}$ warming and cooling events (red). The disadvantage of this approach is that it results in discontinuities in $\lambda(z)$ (the first derivative of the depth-age relationship), which we consider highly unrealistic. A more realistic approach is therefore to assume that $\lambda(z)$ is continuous and smooth (Fudge et al., 2014); Fig. $8 \mathrm{~b}$ shows two scenarios in which we use a spline function to estimate $\lambda(z)$, where again we have applied age constraints from $\mathrm{NH}$ warming events only (orange) or age constraints from both NH warming and cooling events (blue).

For comparison, past $A$ obtained from the firn densification model (Sect. 3) is plotted in green (Fig. 8b). While the $\delta^{15} \mathrm{~N}$-based $A$ follows the synchronization-based $A$ estimates broadly, the millennial-scale details do not agree. We want to point out that this is not unexpected, since both methods have their imperfections. In particular, any errors in the (stretched) GICC05 age model or in our modeled thinning function $f_{\lambda}(z)$ will strongly impact the synchronization-based $A$ estimates in Fig. 8b. The discrepancy is pronounced between 60 and $65 \mathrm{ka}$, where we have to strongly reduce $\lambda(z)$ in order to fit the age constraint(s) from DO 18 , while $\delta^{15} \mathrm{~N}$ provides no evidence for low $A$ during this interval.

For the WD2014 chronology we have applied the smooth $\lambda(z)$ interpolation scheme using all age constraints (i.e., both NH warming and cooling events). The midpoint detection uncertainty is comparable for all events and systematically smaller at the start of interstadial periods than at the terminations (Tables 1 and 2). For short interstadials (e.g., DO 9) this leads to a large relative uncertainty in the event duration, and thereby a large uncertainty in the implied accumulation rates (Fig. 8b). We force the interpolation to fit all NH warming constraints perfectly, yet relax this requirement for $\mathrm{NH}$ cooling constraints to prevent large swings in $\lambda(z)$ for the short-duration events. The WD2014 chronology fits the $\mathrm{NH}$ warming and $\mathrm{NH}$ cooling age constraints with a 0 - and 16-year rms offset, respectively. Because the duration of (inter)stadial periods is well constrained in the layer-counted GICC05 chronology, using both the NH warming and $\mathrm{NH}$ cooling tie points results in a more robust chronology. The duration of (inter)stadial periods is $0.63 \%$ longer in WD2014 than in GICC05, which is well within the stated GICC05 counting error of $5.4 \%$ (31.2-60 ka interval). 

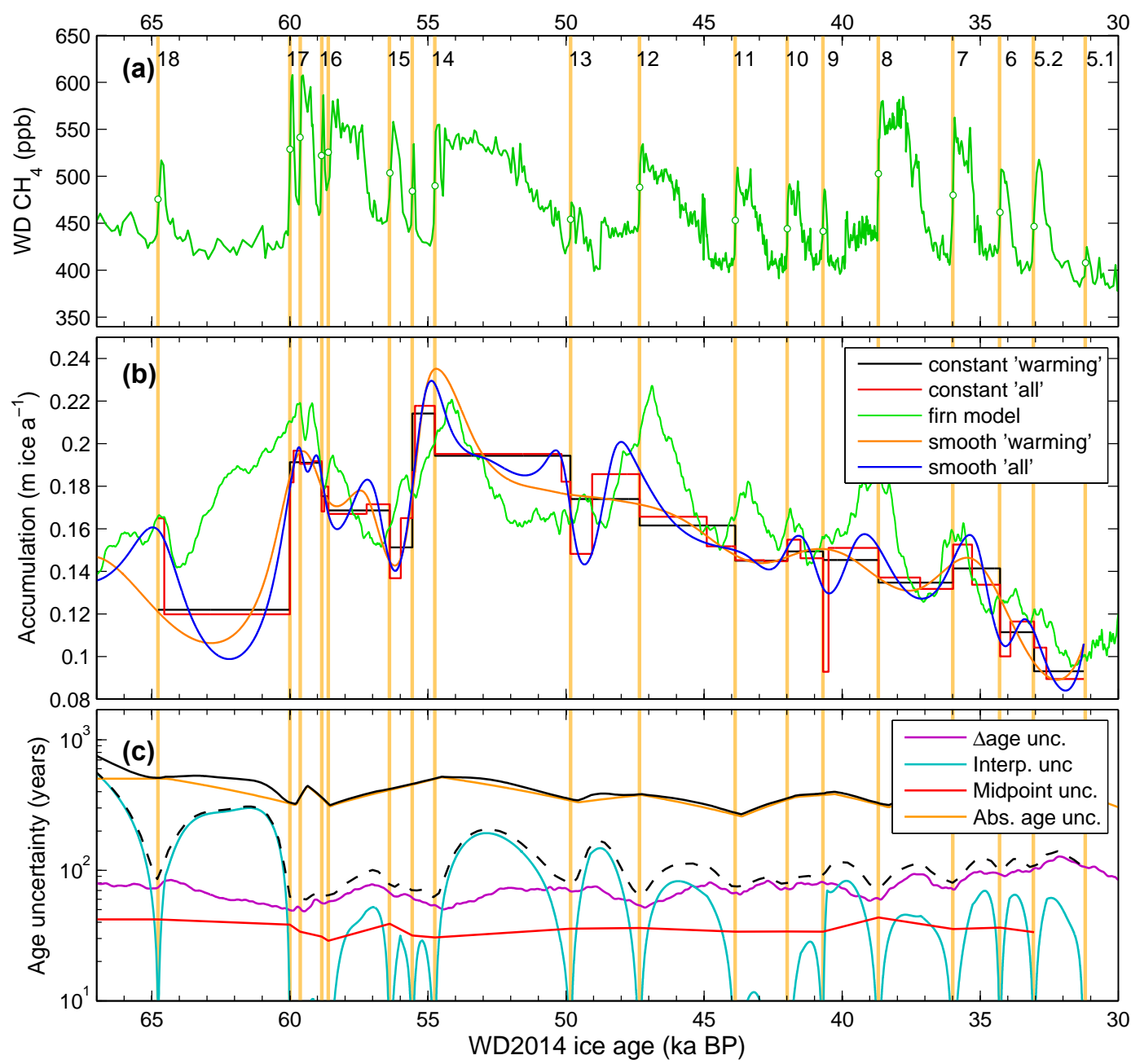

Figure 8. Interpolating between the $\mathrm{CH}_{4}$ age constraints. (a) WD discrete $\mathrm{CH}_{4}$ record with the abrupt stadial-interstadial transitions marked. DO numbering given at the top of the panel. (b) Different annual-layer thickness scenarios, converted to an accumulation rate for comparison to the $\delta^{15} \mathrm{~N}$-based firn model reconstructions. The interpolation strategy is to use either constant accumulation rates between tie points ("constant") or a smoothly varying $\lambda(z)$ ("smooth"); the age constraints used are either only the NH warming events ("warming"), or both the NH warming and cooling events ("all"). (c) Estimated $2 \sigma$ uncertainties in the WD2014 chronology due to $\Delta$ age, choice of interpolation scheme, midpoint detection, and the absolute age constraints used in the synchronization. Total absolute ice age uncertainty plotted in solid black; relative age uncertainty (i.e., with absolute age uncertainty in the Hulu-GICC05 master chronology withheld) plotted in dashed black.

\subsection{Age uncertainty}

The age uncertainty we assign to the deep part ( $>2850 \mathrm{~m}$ ) of the WD2014 chronology has four components.

The first source of uncertainty is the $\Delta$ age calculation; we use the $2 \sigma$ uncertainty obtained in the $\Delta$ age sensitivity study (Sect. 3.2). The second source of uncertainty is the choice of interpolation scheme used to obtain a continuous chronology; here we use the standard deviation between the four different interpolation schemes of Fig. 8b as an uncertainty estimate. The third source of uncertainty is the difficulty in determining the timing of the abrupt events in the time series; we use the uncertainty in the midpoint evaluation (root sum square of $\mathrm{WD} \mathrm{CH}_{4}$ and NGRIP $\delta^{18} \mathrm{O}$ estimates). The last source of uncertainty is the age uncertainty in the hybrid NGRIP-Hulu chronology that we synchronize to. We use the stated Hulu age uncertainty plus 50 years to account for possible leads or lags in the NGRIP-Hulu $\delta^{18} \mathrm{O}$ phasing, plus the absolute value of the offset between the Hulu ages and the $1.0063 \times$ GICC05 ages. For DO events where we do not have reliable Hulu age estimates (Table 1), we set the uncertainty to the Hulu age uncertainty of the nearest event, plus the uncertainty in the interval duration specified by the GICC05 layer count. For example, for DO 14 we do not have a reliable Hulu age estimate, and we use the Hulu age uncertainty of DO 16.2 (226 years) plus the uncertainty in the DO 14 to DO 16.2 interval duration on GICC05 (209 years), giving a total of $226+209=435$ years. 
Table 2. Overview of $\mathrm{CH}_{4}$ tie points for $\mathrm{NH}$ cooling events. WD ages printed in boldface are assigned as part of the $\mathrm{CH}_{4}$ synchronization; all other ages are on their independent chronologies

\begin{tabular}{|c|c|c|c|c|c|c|c|c|}
\hline & \multicolumn{4}{|c|}{ NGRIP } & \multicolumn{4}{|c|}{ WD } \\
\hline & $\begin{array}{r}\text { Depth } \\
(\mathrm{m})\end{array}$ & $\begin{array}{r}\text { Age } \\
\text { (years BP) }\end{array}$ & $\begin{array}{r}\text { Age uncert. } \\
\text { (years) }\end{array}$ & $\begin{array}{r}\text { Midpoint } \\
\text { (years) }\end{array}$ & $\begin{array}{r}\text { Depth } \\
(\mathrm{m})\end{array}$ & $\begin{array}{r}\text { Gas age } \\
\text { (years BP) }\end{array}$ & $\begin{array}{r}\text { Ice age } \\
\text { (years BP) }\end{array}$ & $\begin{array}{r}\text { Midpoint } \\
\text { (years) }\end{array}$ \\
\hline BA-YD & 1524.21 & 12775 & 136 & 81 & 2096.61 & 12769 & 12987 & 52 \\
\hline DO 3 & 1861.91 & 27498 & 822 & 52 & 2747.25 & 27520 & 27905 & 38 \\
\hline DO 4 & 1882.59 & 28548 & 887 & 17 & 2787.99 & 28696 & 29090 & 61 \\
\hline DO 5.1 & 1916.45 & 30571 & 1010 & 70 & 2845.37 & 30618 & 31067 & 50 \\
\hline DO 5.2 & 1939.71 & 31992 & 1108 & 13 & 2875.86 & 32168 & 32607 & 70 \\
\hline DO 6 & 1964.52 & 33323 & 1192 & 37 & 2905.55 & 33508 & 33905 & 60 \\
\hline DO 7 & 1990.58 & 34703 & 1286 & 13 & 2939.09 & 34897 & 35292 & 50 \\
\hline DO 8 & 2027.43 & 36571 & 1401 & 21 & 2986.58 & 36776 & 37172 & 32 \\
\hline DO 9 & 2095.51 & 39905 & 1572 & 42 & 3063.79 & 40132 & 40492 & 25 \\
\hline DO 10 & 2112.53 & 40917 & 1621 & 44 & 3083.89 & 41150 & 41508 & 44 \\
\hline DO 11 & 2135.66 & 42231 & 1685 & 27 & 3110.76 & 42472 & 42823 & 69 \\
\hline DO 12 & 2171.17 & 44308 & 1783 & 41 & 3149.89 & 44562 & 44904 & 47 \\
\hline DO 13 & 2242.85 & 48440 & 1996 & 27 & 3226.93 & 48720 & 49054 & 20 \\
\hline DO 14 & 2261.49 & 49552 & 2052 & 20 & 3243.03 & 49839 & 50165 & 65 \\
\hline DO 15.1 & 2353.66 & 54850 & 2339 & 18 & 3321.15 & 55170 & 55469 & 14 \\
\hline DO 15.2 & 2359.92 & 55369 & 2370 & 55 & 3326.47 & 55693 & 55983 & 45 \\
\hline DO 16.1 & 2375.88 & 56555 & 2435 & 49 & 3337.98 & 56887 & 57219 & 76 \\
\hline DO 16.2 & 2400.56 & 58123 & 2508 & 15 & 3351.80 & 58465 & 58756 & 9 \\
\hline DO 17.1 & 2406.52 & 58544 & 2530 & 35 & 3355.54 & 58888 & 59151 & 61 \\
\hline DO 17.2 & 2417.77 & 59257 & 2570 & 18 & 3362.26 & 59606 & 59862 & 24 \\
\hline DO 18 & 2462.07 & 63810 & 2611 & 14 & 3387.28 & 64187 & 64547 & 32 \\
\hline
\end{tabular}

The uncertainties ( $2 \sigma$ values) are plotted in Fig. $8 \mathrm{c}$ (log scale). We assume these four uncertainties to be independent, and use their root sum square as the total uncertainty estimate on the WD2014 ice age scale (Fig. 8c, black curve). Note that the fourth source of uncertainty is only relevant when considering absolute ages; when evaluating relative ages (e.g., between WD ice and WD gas phase, or between WD and NGRIP), this last contribution does not need to be considered. For the deepest WD ice (3404 m depth) we thus find an age of $67.7 \pm 0.9 \mathrm{kaBP}$.

\section{Discussion}

While the WAIS Divide ice core does not extend as far back in time as deep cores from the East Antarctic Plateau, its relatively high temporal resolution (due to the high snow accumulation rate) makes it an ice core of great scientific value. WD accumulation rate during the LGM $\left(\sim 10 \mathrm{~cm} \mathrm{a}^{-1}\right.$ ice equivalent) is still higher than the present-day accumulation rate at the EPICA (European Project for Ice Coring in Antarctica) Dronning Maud Land core $\left(7 \mathrm{~cm} \mathrm{a}^{-1}\right)$, which is generally considered a high-accumulation core (EPICA Community Members, 2006). With $68 \mathrm{ka}$ in $3404 \mathrm{~m}$ of core, the core average $\lambda$ is $5 \mathrm{cma}^{-1}$, at the onset of the last deglaciation (18 kaBP) $\lambda$ is around $4 \mathrm{~cm} \mathrm{a}^{-1}$, and near the bed $\lambda$ is around $0.4 \mathrm{cma}^{-1}$. This high temporal resolution provides the opportunity for obtaining very detailed climatic records.

High accumulation rates also result in a small $\Delta$ age. Figure 9 compares $\Delta$ age between several Antarctic cores (note the logarithmic scale). $\triangle$ age at WD is approximately onethird of the $\triangle$ age at EPICA DML (EDML) and Talos Dome (TALDICE), and one-tenth of the $\triangle$ age at EPICA Dome C (EDC), Vostok, and Dome Fuji. Because the uncertainty in the $\Delta$ age (or $\Delta$ depth) calculation is typically on the order of $20 \%$, a smaller $\Delta$ age allows for a more precise interhemispheric synchronization with Greenland ice core records using $\mathrm{CH}_{4}$. The small WD $\Delta$ age uncertainty during MIS 3 allows for investigation of the phasing of the bipolar seesaw (Stocker and Johnsen, 2003) at sub-centennial precision (WAIS Divide Project Members, 2015).

In comparing the shape of the $\Delta$ age profiles, there are some interesting differences (Fig. 9). It is important to realize that not all the $\Delta$ age histories shown were derived in the same way; WD and Dome Fuji $\Delta$ age were derived using densification models, and the other four were derived using the $\Delta$ depth approach (Parrenin et al., 2012) and a Bayesian inverse method that includes a wide range of age markers (Veres et al., 2013). We will therefore focus on comparing the WD and Dome Fuji results. $\triangle$ age at WD shows more pronounced variability than at Dome Fuji, particularly during MIS 3. The reason is that the glacial firn pack at Dome 
Fuji is about 4000 years old, and consequently the firn column integrates over 4000 years of climate variability, thereby dampening the $\Delta$ age response to millennial-scale climatic variability. At WD the glacial firn layer is only about 350 years old, and therefore the firn is in near equilibrium with the millennial-scale climate variations. This difference in response time is also obvious during the deglaciation, where WD $\Delta$ age transitions from glacial to interglacial values between 18 and $14.5 \mathrm{kaBP}$, while Dome Fuji takes more time (18-10 kaBP). Surprisingly, EDML $\triangle$ age does not show a strong deglacial $\Delta$ age response, unlike all the other cores.

The relatively small $\Delta$ age at WAIS Divide also allows for precise investigation of the relative timing of atmospheric greenhouse gas variations and Antarctic climate (Barnola et al., 1991; Pedro et al., 2012; Caillon et al., 2003; Parrenin et al., 2013; Ahn et al., 2012). Recent works suggest that during the last deglaciation the rise in atmospheric $\mathrm{CO}_{2}$ lagged the onset of pan-Antarctic warming by approximately 0 to 400 years (Pedro et al., 2012; Parrenin et al., 2013). This Antarctic warming around $18 \mathrm{kaBP}$ is presumably driven by the bipolar seesaw, as it coincides with a reduction in Atlantic overturning circulation strength as seen in North Atlantic sediment records (McManus et al., 2004). The WD $\Delta$ age at $18 \mathrm{ka}$ (gas age) is $515 \pm 91$ years $(2 \sigma)$, much smaller than at central East Antarctic sites such as EPICA Dome $\mathrm{C}$, where $\Delta$ age is approximately $3850 \pm 900$ years (Veres et al., 2013, with the $\Delta$ age uncertainty taken to be the difference between the gas age and ice age uncertainties). The precision with which one can determine the relative phasing of climatic (i.e., $\delta^{18} \mathrm{O}$ of ice) and atmospheric signals is set by the uncertainty in $\Delta$ age (or equivalently, the uncertainty in $\Delta$ depth). High-resolution WD records of $\mathrm{CO}_{2}$ and $\mathrm{CH}_{4}$ (Marcott et al., 2014) place the onset of the deglacial rise in the atmospheric mixing ratio of these greenhouse gases on the WD2014 chronology at 18010 and 17820 years BP, respectively. However, evaluating the relative phasing of $\mathrm{CO}_{2}$ and Antarctic climate is complicated by the observation of asynchronous deglacial warming across the Antarctic continent (WAIS Divide Project Members, 2013). Attempts to capture the climate- $\mathrm{CO}_{2}$ relationship in a single lead-lag value may be an oversimplification of deglacial climate dynamics.

An important next step will be to synchronize the WD chronology with other Antarctic cores via volcanic matching and other age markers (e.g., Severi et al., 2007; Sigl et al., 2014). Because of the annual-layer count and possibility of tight synchronization to Greenland ice cores, WD could contribute to an improved absolute dating of Antarctic cores, as well as improved cross-dating between cores. Such cross-dating could help inform the WD chronology as well, particularly in the deepest part of the core, where the ice is potentially highly strained, as suggested by the interpolation difficulties in the 60-65 ka interval (Fig. 8b). With a synchronized chronology, WD could improve the representation of West Antarctic climate in Antarctic ice core stacks (Pedro

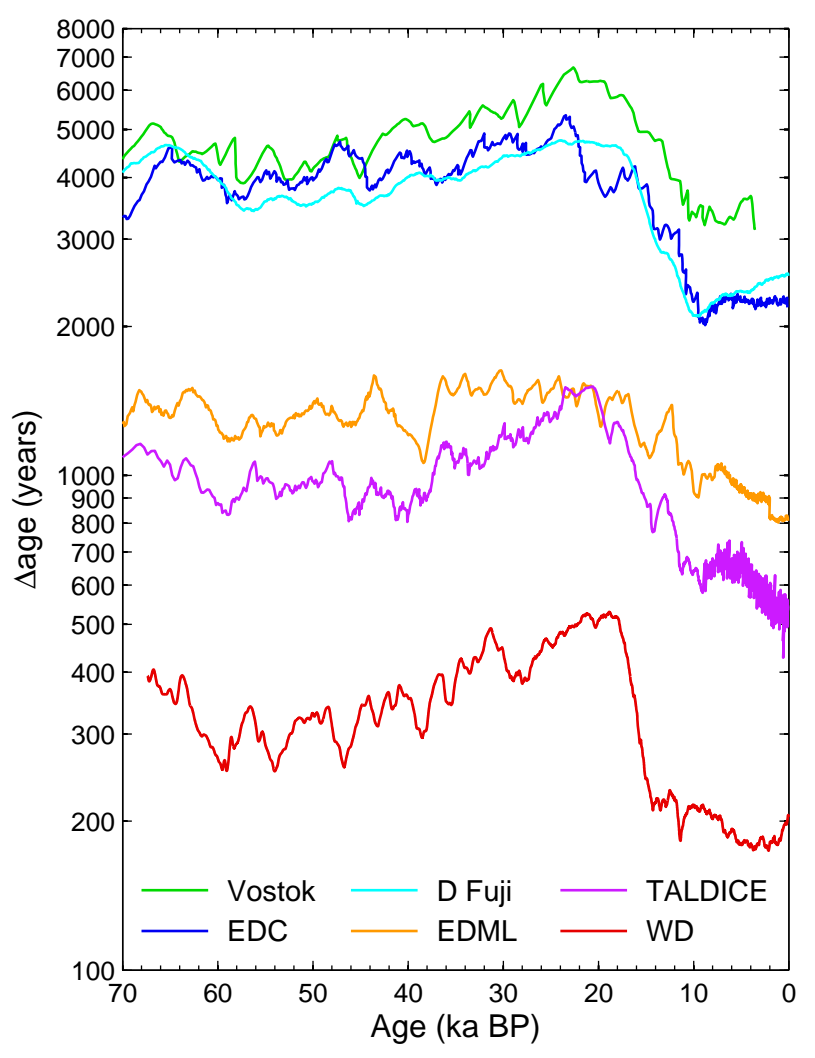

Figure 9. Comparison of $\Delta$ age for different Antarctic cores, plotted on the gas age scale. Dome Fuji $\Delta$ age from Kawamura et al. (2007); WD from Sect. 3; all others from Bazin et al. (2013); Veres et al. (2013).

et al., 2011; Parrenin et al., 2013), and provide a more refined pan-Antarctic picture of the climate- $\mathrm{CO}_{2}$ relationship.

\section{Summary and conclusions}

We have presented a first chronology for the deep (> 2850 m) section of the WAIS Divide ice core, which is based on stratigraphic matching to Greenland ice cores using globally well-mixed methane. We use a dynamical firn densification model constrained by $\delta^{15} \mathrm{~N}$ data to calculate past $\Delta$ age, and find that $\Delta$ age was smaller than $525 \pm 120$ years for all of the core. Using high-resolution WD records of atmospheric $\mathrm{CH}_{4}$, we synchronize WD directly to Greenland NGRIP $\delta^{18} \mathrm{O}$ for the abrupt onset and termination of each of the DO interstadials. To each event we assign an age corresponding to 1.0063 times its GICC05 age, which brings the ages in agreement with the high-resolution $\mathrm{U} /$ Th-dated Hulu speleothem record. The uncertainty in the final chronology is based on the uncertainties in (i) the $\Delta$ age calculations, as evaluated with a sensitivity study; (ii) the interpolation strategy, as evaluated by comparing four different interpolation methods; (iii) determining the timing of events in the 
different time series; and (iv) the ages of the hybrid NGRIPHulu chronology we are synchronizing to.

Due to the combination of a small $\Delta$ age and a highresolution methane record, the WAIS Divide ice core can be synchronized more precisely to Greenland records than any other Antarctic core to date. This is important when investigating interhemispheric climate relationships such as the bipolar seesaw. The small WD $\Delta$ age furthermore provides valuable opportunities for precise investigation of the relative phasing of atmospheric greenhouse gas variations and Antarctic climate.

\section{Appendix A: Densification physics}

The densification rates used in this work are based on the empirical steady-state model by Herron and Langway (1980) (the H-L model). We use the H-L model with minor modifications that allow it to be run dynamically (i.e., with timevariable $T$ and $A$ ) and to include the softening effect of impurities following Freitag et al. (2013a). The H-L model divides the firn column in two stages, separated at the critical density $\rho_{\mathrm{c}}=550 \mathrm{~kg} \mathrm{~m}^{-3}$, occurring at the critical depth $z_{\mathrm{c}}$.

For the upper firn $\left(\rho \leq \rho_{\mathrm{c}}\right.$, stage 1$)$, the densification rates are given by

$\frac{\mathrm{d} \rho}{\mathrm{d} t}=k_{1} A\left(\rho_{\text {ice }}-\rho\right)$,

with

$k_{1}=11 \exp \left(-\frac{E_{1}}{R T}\right)$,

where $E_{1}=10.16 \mathrm{~kJ} \mathrm{~mol}^{-1}$ is the activation energy for stage 1 and $R$ is the universal gas constant. Because both the sinking velocity of deposited layers $(w=\mathrm{d} z / \mathrm{d} t)$ and the densification rate scale linearly with $A$, the resulting density-depth profile $\rho(z)$ in stage 1 becomes independent of $A$, and sensitive to $T$ variations only.

For the deeper firn $\left(\rho>\rho_{\mathrm{c}}\right.$, stage 2$)$, we use Eq. (4c) from Herron and Langway (1980), which was first derived by Sigfús J. Johnsen. This equation gives the densification rate in terms of overburden load, which allows the model to be run dynamically. The stage 2 densification rates are given by

$\frac{\mathrm{d} \rho}{\mathrm{d} t}=k_{2}^{2} \frac{\left(\sigma_{z}-\sigma_{z_{\mathrm{c}}}\right)\left(\rho_{\text {ice }}-\rho\right)}{\ln \left[\left(\rho_{\text {ice }}-\rho_{\mathrm{c}}\right) /\left(\rho_{\text {ice }}-\rho\right)\right]}$,

with

$k_{2}=575 \exp \left(-\frac{E_{2}}{R T}\right)$,

where $E_{2}=21.4 \mathrm{~kJ} \mathrm{~mol}^{-1}$ is the activation energy for stage 2 and $\sigma_{z}$ denotes the firn overburden load at a given depth in $\mathrm{Mg} \mathrm{m}^{-2}$ :

$\sigma_{z}=\int_{0}^{z} \rho\left(z^{\prime}\right) \mathrm{d} z^{\prime} / 1000$.

Note that we divide by 1000 to convert from $\mathrm{kg} \mathrm{m}^{-3}$ to $\mathrm{Mg} \mathrm{m}^{-3}$, the units used by Herron and Langway (1980).

We use the mathematical description by Freitag et al. (2013a) to include the hypothesized firn softening effect of impurities. In this approach an increasing $\mathrm{Ca}$ concentration, as a proxy for mineral dust content, lowers the activation energy of firn, thereby enhancing densification rates. This is tantamount to stating that dusty firn behaves as if it were "warmer" than its climatological temperature. The H-L activation energies of Eqs. (A2) and (A4) are modified by [Ca] in the following way:

$E^{\mathrm{Ca}}=E^{\mathrm{HL}} \times \alpha\left[1-\beta \ln \left(\frac{[\mathrm{Ca}]}{[\mathrm{Ca}]_{\text {crit }}}\right)\right]$,

where $E^{\mathrm{Ca}}$ and $E^{\mathrm{HL}}$ are the Ca-modified and original H-L activation energies, respectively, $[\mathrm{Ca}]_{\text {crit }}=0.5 \mathrm{ng} \mathrm{g}^{-1}$ is the minimum concentration at which impurities affect densification, and $\alpha$ and $\beta$ are calibration parameters. Whenever $[\mathrm{Ca}](z)<[\mathrm{Ca}]_{\text {crit }}$, we set $[\mathrm{Ca}](z)=[\mathrm{Ca}]_{\text {crit }}$.

The parameter $\beta$ sets the sensitivity to dust loading, and $\alpha$ is a normalization parameter that is included to account for the fact that the original H-L model was calibrated without the impurity effect. Consequently, if $\beta>0$, one needs to compensate by setting $\alpha>1$ to preserve the original $\mathrm{H}$ L calibration. The work by Freitag et al. (2013a) recommends $\beta=0.01$ and $\alpha=1.025$ (which yields $E^{\mathrm{Ca}}=E^{\mathrm{HL}}$ at $[\mathrm{Ca}]=5.73 \mathrm{ng} \mathrm{g}^{-1}$ ).

Using the recommended value of $\alpha=1.025$ at WD provides a poor fit to observations of present-day firn density and close-off depth. The optimal fit to present-day WD observations is obtained using an activation energy equal to $1.007 \times E^{\mathrm{HL}}$; this is in between the values suggested by Herron and Langway (1980) and Freitag et al. (2013a). In the experiment presented in Fig. 4 we changed the dust sensitivity $\beta$; it is clear that we need to simultaneously change $\alpha$ to keep the model well-calibrated to present-day conditions. Due to the fact that the mean late Holocene WD [Ca] is around $0.8 \mathrm{ng} \mathrm{g}^{-1}$, we let $\alpha=1.007 /(1-\beta \ln [0.8 / 0.5])$ in the experiment of Fig. 4. This approach ensures that the present-day $E^{\mathrm{Ca}}$ is invariant with $\beta$, and equals $E^{\mathrm{Ca}}=1.007 \times E^{\mathrm{HL}}$. This means that whatever value we choose for $\beta$, we will obtain a good fit to the present-day $\Delta$ age, $\delta^{15} \mathrm{~N}$, and $A$ values that are well known from direct observations (Battle et al., 2011).

To validate the H-L model $\Delta$ age simulations, we repeated the firn modeling using the densification physics of Arnaud et al. (2000), which is also the basis of the model by Goujon et al. (2003). Our implementation of the Arnaud model is based on the description in the latter paper, with one modification at the critical density that we outline here. 
In the Arnaud model, densification in the stage 1 follows the work of Alley (1987), and is given by

$$
\frac{\mathrm{d} D}{\mathrm{~d} t}=\gamma\left(\frac{P}{D^{2}}\right)\left(1-\frac{5}{3} D\right)
$$

with $D$ the relative density $D=\rho / \rho_{\text {ice }}, P$ the overburden pressure, and $\gamma$ a scaling factor used to make the densification rates continuous across the critical density $D_{\mathrm{c}}$. Stage 2 densification is given by

$$
\frac{\mathrm{d} D}{\mathrm{~d} t}=k_{\mathrm{A}}\left(D^{2} D_{\mathrm{c}}\right)^{\frac{1}{3}}\left(\frac{a}{\pi}\right)^{\frac{1}{2}}\left(\frac{4 \pi P}{3 a Z D}\right)^{3},
$$

with

$k_{\mathrm{A}}=4.182 \times 10^{4} \exp \left(-\frac{E_{\mathrm{A}}}{R T}\right)$,

where $a$ is the average contact area between the grains, $Z$ is the coordination number, and $E_{\mathrm{A}}$ is the activation energy $\left(60 \mathrm{~kJ} \mathrm{~mol}^{-1}\right)$. Arnaud densification rates for stage 3 $(D \geq 0.9)$ are describe elsewhere (Goujon et al., 2003; Arnaud et al., 2000).

The difficulty in implementing this model is the following. The densification rates of Eqs. (A7-A8) exhibit a discontinuity at the critical density $D=D_{\mathrm{c}}=0.6$ that cannot be remedied with the scaling factor $\gamma$. On approaching $D_{\mathrm{c}}$, densification rates given by Eq. (A7) go to zero (due to the inclusion of the term $\left(1-\frac{5}{3} D\right)$, while densification rates given by Eq. (A8) go to infinity because the contact area $a$ equals zero at $D=D_{\text {c. }}$. Clearly neither equation gives a realistic result

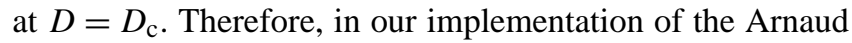
model we use the H-L densification rates of Eq. (A1) instead of Eq. (A7) in stage 1. We take the onset of stage 2 to be the density at which Eqs. (A1) and (A8) intercept, thus avoiding the singularity in Eq. A8. This approach has the additional advantages of removing dependence on ad hoc scaling factor $\gamma$ and introducing realistic temperature dependence for stage 1 densification. Because stage 1 spans just the top 10-20\% of the firn column, the modification has only a minor influence on the overall behavior of the Arnaud model. The Goujon model code avoids the singularity in Eq. (A8) by extending stage 1 to $D_{\mathrm{c}}+\varepsilon$ (Anaïs Orsi, personal communication, 2014), a procedure not described in Goujon et al. (2003).

\section{The Supplement related to this article is available online at doi:10.5194/cp-11-153-2015-supplement.}

Acknowledgements. We thank Mark Twickler and Joseph Souney Jr. of the WAIS Divide Science Coordination Office; the Ice Drilling Design and Operations group at the University of Wisconsin for recovering the ice core; O. Maselli, N. Chellman, M. Grieman, J. D'Andrilli, L. Layman, and R. Grinstead for help in making the continuous $\mathrm{CH}_{4}$ and $\mathrm{Ca}$ measurements; A. J. Schauer, S. W. Schoenemann, P. D. Neff, and B. Vanden Heuvel for help in making the water-isotopologue measurements; Raytheon Polar Services for logistics support in Antarctica; the $109^{\text {th }}$ New York Air National Guard for airlift in Antarctica; Anaïs Orsi for fruitful discussions; Dan Muhs for feedback on the manuscript; and the dozens of core handlers in the field and at the National Ice Core Laboratory for the core processing. This work is funded by the US National Science Foundation through grants 0539232, 0537661 (to K. M. Cuffey), ANT05-38657 (to J. P. Severinghaus.), NSFC 41230524 (to H. Cheng. and R. L. Edwards), 0839093, 1142166 (to J. R. McConnell.), and 1043092 (to E. J. Steig.) and through grants $0230396,0440817,0944348$, and 0944266 to the Desert Research Institute of Reno Nevada and University of New Hampshire for the collection and distribution of the WAIS Divide ice core and related tasks. We further acknowledge support by the NOAA Climate and Global Change fellowship program, administered by the University Corporation for Atmospheric Research (to C. Buizert.) and the Villum Foundation (to M. Winstrup.).

Edited by: H. Fischer

\section{References}

Aciego, S., Bourdon, B., Schwander, J., Baur, H., and Forieri, A.: Toward a radiometric ice clock: uranium ages of the Dome $\mathrm{C}$ ice core, Quaternary Sci. Rev., 30, 2389-2397, 2011.

Ahn, J. and Brook, E. J.: Atmospheric $\mathrm{CO}_{2}$ and climate on millennial time scales during the last glacial period, Science, 322, 83-85, 2008.

Ahn, J., Brook, E. J., Schmittner, A., and Kreutz, K.: Abrupt change in atmospheric $\mathrm{CO}_{2}$ during the last ice age, Geophys. Res. Lett., 39, L18711, doi:10.1029/2012g1053018, 2012.

Alley, R. B.: Firn densification by grain-boundary sliding - a 1 st model, Journal De Physique, 48, 249-256, 1987.

Arnaud, L., Barnola, J. M., and Duval, P.: Physical modeling of the densification of snow/firn and ice in the upper part of polar ice sheets, in: Physics of Ice Core Records, edited by Hondoh, T., 285-305, 2000.

Barnola, J. M., Pimienta, P., Raynaud, D., and Korotkevich, Y. S.: $\mathrm{CO}_{2}$-climate relationship as deduced from the Vostok ice core: a re-examination based on new measurements and on a reevaluation of the air dating, Tellus B., 43, 83-90, 1991.

Battle, M. O., Severinghaus, J. P., Sofen, E. D., Plotkin, D., Orsi, A. J., Aydin, M., Montzka, S. A., Sowers, T., and Tans, P. P.: Controls on the movement and composition of firn air at the West Antarctic Ice Sheet Divide, Atmos. Chem. Phys., 11, 1100711021, doi:10.5194/acp-11-11007-2011, 2011.

Baumgartner, M., Kindler, P., Eicher, O., Floch, G., Schilt, A., Schwander, J., Spahni, R., Capron, E., Chappellaz, J., Leuenberger, M., Fischer, H., and Stocker, T. F.: NGRIP $\mathrm{CH}_{4}$ concentration from 120 to $10 \mathrm{kyr}$ before present and its relation to a $\delta^{15} \mathrm{~N}$ temperature reconstruction from the same ice core, Clim. Past, 10, 903-920, doi:10.5194/cp-10-903-2014, 2014.

Bazin, L., Landais, A., Lemieux-Dudon, B., Toyé Mahamadou Kele, H., Veres, D., Parrenin, F., Martinerie, P., Ritz, C., Capron, E., Lipenkov, V., Loutre, M.-F., Raynaud, D., Vinther, B., Svensson, A., Rasmussen, S. O., Severi, M., Blunier, T., Leuenberger, M., Fischer, H., Masson-Delmotte, V., Chappellaz, J., and Wolff, E.: An optimized multi-proxy, 
multi-site Antarctic ice and gas orbital chronology (AICC2012): 120-800 ka, Clim. Past, 9, 1715-1731, doi:10.5194/cp-9-17152013, 2013.

Bendel, V., Ueltzhoffer, K. J., Freitag, J., Kipfstuhl, S., Kuhs, W. F., Garbe, C. S., and Faria, S. H.: High-resolution variations in size, number and arrangement of air bubbles in the EPICA DML (Antarctica) ice core, J. Glaciol., 59, 972-980, 2013.

Bender, M. L.: Orbital tuning chronology for the Vostok climate record supported by trapped gas composition, Earth Planet. Sc. Lett., 204, 275-289, 2002.

Bender, M. L., Barnett, B., Dreyfus, G., Jouzel, J., and Porcelli, D.: The contemporary degassing rate of Ar-40 from the Solid Earth, P. Natl. Acad. Sci. USA, 105, 8232-8237, 2008.

Blunier, T. and Brook, E. J.: Timing of millennial-scale climate change in Antarctica and Greenland during the last glacial period, Science, 291, 109-112, 2001.

Blunier, T. and Schwander, J.: Gas enclosure in ice: age difference and fractionation, in: Physics of Ice Core Records, edited by: Hondoh, T., Hokkaido University Press, Sapporo, 307-326, 2000.

Blunier, T., Chappellaz, J., Schwander, J., Dallenbach, A., Stauffer, B., Stocker, T. F., Raynaud, D., Jouzel, J., Clausen, H. B., Hammer, C. U., and Johnsen, S. J.: Asynchrony of Antarctic and Greenland climate change during the last glacial period, Nature, 394, 739-743, 1998.

Blunier, T., Spahni, R., Barnola, J.-M., Chappellaz, J., Loulergue, L., and Schwander, J.: Synchronization of ice core records via atmospheric gases, Clim. Past, 3, 325-330, doi:10.5194/cp3-325-2007, 2007.

Broccoli, A. J., Dahl, K. A., and Stouffer, R. J.: Response of the ITCZ to Northern Hemisphere cooling, Geophys. Res. Lett., 33, L01702, doi:10.1029/2005g1024546, 2006.

Brook, E. J., Sowers, T., and Orchardo, J.: Rapid variations in atmospheric methane concentration during the past 110,000 years, Science, 273, 1087-1091, 1996.

Buizert, C., Martinerie, P., Petrenko, V. V., Severinghaus, J. P., Trudinger, C. M., Witrant, E., Rosen, J. L., Orsi, A. J., Rubino, M., Etheridge, D. M., Steele, L. P., Hogan, C., Laube, J. C., Sturges, W. T., Levchenko, V. A., Smith, A. M., Levin, I., Conway, T. J., Dlugokencky, E. J., Lang, P. M., Kawamura, K., Jenk, T. M., White, J. W. C., Sowers, T., Schwander, J., and Blunier, T.: Gas transport in firn: multiple-tracer characterisation and model intercomparison for NEEM, Northern Greenland, Atmos. Chem. Phys., 12, 4259-4277, doi:10.5194/acp-12-42592012, 2012.

Buizert, C., Sowers, T., and Blunier, T.: Assessment of diffusive isotopic fractionation in polar firn, and application to ice core trace gas records, Earth Planet. Sc. Lett., 361, 110-119, doi:10.1016/j.eps1.2012.11.039, 2013.

Buizert, C., Baggenstos, D., Jiang, W., Purtschert, R., Petrenko, V. V., Lu, Z.-T., Muller, P., Kuhl, T., Lee, J., Severinghaus, J. P., and Brook, E. J.: Radiometric ${ }^{81} \mathrm{Kr}$ dating identifies 120,000-year-old ice at Taylor Glacier, Antarctica, P. Natl. Acad. Sci. USA, 111, 6876-6881, 2014a.

Buizert, C., Gkinis, V., Severinghaus, J. P., He, F., Lecavalier, B. S., Kindler, P., Leuenberger, M., Carlson, A. E., Vinther, B., Masson-Delmotte, V., White, J. W. C., Liu, Z., Otto-Bliesner, B., and Brook, E. J.: Greenland temperature response to climate forcing during the last deglaciation, Science, 345, 1177-1180, 2014b.

Caillon, N., Severinghaus, J. P., Jouzel, J., Barnola, J.-M., Kang, J., and Lipenkov, V. Y.: Timing of atmospheric $\mathrm{CO}_{2}$ and antarctic temperature changes across termination III, Science, 299, 17281731, doi:10.1126/science.1078758, 2003.

Capron, E., Landais, A., Chappellaz, J., Schilt, A., Buiron, D., DahlJensen, D., Johnsen, S. J., Jouzel, J., Lemieux-Dudon, B., Loulergue, L., Leuenberger, M., Masson-Delmotte, V., Meyer, H., Oerter, H., and Stenni, B.: Millennial and sub-millennial scale climatic variations recorded in polar ice cores over the last glacial period, Clim. Past, 6, 345-365, doi:10.5194/cp-6-3452010, 2010.

Capron, E., Landais, A., Buiron, D., Cauquoin, A., Chappellaz, J., Debret, M., Jouzel, J., Leuenberger, M., Martinerie, P., MassonDelmotte, V., Mulvaney, R., Parrenin, F., and Prié, F.: Glacialinterglacial dynamics of Antarctic firn columns: comparison between simulations and ice core air- $\delta^{15} \mathrm{~N}$ measurements, Clim. Past, 9, 983-999, doi:10.5194/cp-9-983-2013, 2013.

Chappellaz, J., Stowasser, C., Blunier, T., Baslev-Clausen, D., Brook, E. J., Dallmayr, R., Faïn, X., Lee, J. E., Mitchell, L. E., Pascual, O., Romanini, D., Rosen, J., and Schüpbach, S.: Highresolution glacial and deglacial record of atmospheric methane by continuous-flow and laser spectrometer analysis along the NEEM ice core, Clim. Past, 9, 2579-2593, doi:10.5194/cp-92579-2013, 2013.

Chiang, J. C. H. and Bitz, C. M.: Influence of high latitude ice cover on the marine Intertropical Convergence Zone, Clim. Dynam., 25, 477-496, 2005.

Cuffey, K. M. and Clow, G. D.: Temperature, accumulation, and ice sheet elevation in central Greenland through the last deglacial transition, J. Geophys. Res., 102, 26383-26396, 1997.

Cuffey, K. M. and Paterson, W. S. B.: The Physics of Glaciers, 4th edn., Butterworth-Heinemann, Oxford, UK, 2010.

Cuffey, K. M., Clow, G. D., Alley, R. B., Stuiver, M., Waddington, E. D., and Saltus, R. W.: Large arctic temperature change at the Wisconsin-Holocene glacial transition, Science, 270, 455458, 1995.

Cvijanovic, I. and Chiang, J. C. H.: Global energy budget changes to high latitude North Atlantic cooling and the tropical ITCZ response, Clim. Dynam., 40, 1435-1452, 2013.

Dahl-Jensen, D., Mosegaard, K., Gundestrup, N., Clow, G. D., Johnsen, S. J., Hansen, A. W., and Balling, N.: Past temperatures directly from the greenland ice sheet, Science, 282, 268271, 1998.

Dansgaard, W. and Johnsen, S.: A flow model and a time scale for the ice core from Camp Century, Greenland, J. Glaciol., 8, 215223, 1969.

Dlugokencky, E., Myers, R., Lang, P., Masarie, K., Crotwell, A., Thoning, K., Hall, B., Elkins, J., and Steele, L.: Conversion of NOAA atmospheric dry air $\mathrm{CH}_{4}$ mole fractions to a gravimetrically prepared standard scale, J. Geophys. Res.-Atmos., 110, D18306, doi:10.1029/2005JD006035, 2005.

Dreyfus, G. B., Jouzel, J., Bender, M. L., Landais, A., MassonDelmotte, V., and Leuenberger, M.: Firn processes and $\delta^{15} \mathrm{~N}$ : potential for a gas-phase climate proxy, Quaternary Sci. Rev., 29, 28-42, 2010

Edwards, R. L., Cheng, H., Wang, Y. J., Yuan, D. X., Kelly, M. J., Severinghaus, J. P., Burnett, A., Wang, X. F., Smith, E., and 
Kong, X. G.: A Refined Hulu and Dongge Cave Climate Record and the Timing of Climate Change during the Last Glacial Cycle, Earth Planet. Sci. Lett., in review, 2015.

EPICA Community Members: One-to-one coupling of glacial climate variability in Greenland and Antarctica, Nature, 444, 195198, 2006

Etheridge, D. M., Pearman, G. I., and Fraser, P. J.: Changes in tropospheric methane between 1841 and 1978 from a high accumulation-rate Antarctic ice core, Tellus B, 44, 282-294, 1992.

Fleitmann, D., Cheng, H., Badertscher, S., Edwards, R. L., Mudelsee, M., Gokturk, O. M., Fankhauser, A., Pickering, R., Raible, C. C., Matter, A., Kramers, J., and Tuysuz, O.: Timing and climatic impact of Greenland interstadials recorded in stalagmites from northern Turkey, Geophys. Res. Lett., 36, L19707, doi:10.1029/2009g1040050, 2009.

Freitag, J., Kipfstuhl, J., Laepple, T., and Wilhelms, F.: Impuritycontrolled densification: a new model for stratified polar firn, J. Glaciol., 59, 1163-1169, 2013a.

Freitag, J., Kipfstuhl, S., and Laepple, T.: Core-scale radioscopic imaging: a new method reveals density-calcium link in Antarctic firn, J. Glaciol., 59, 1009-1014, 2013b.

Fudge, T. J., Waddington, E. D., Conway, H., Lundin, J. M. D., and Taylor, K.: Interpolation methods for Antarctic ice-core timescales: application to Byrd, Siple Dome and Law Dome ice cores, Clim. Past, 10, 1195-1209, doi:10.5194/cp-10-1195-2014, 2014.

Fujita, S., Hirabayashi, M., Goto-Azuma, K., Dallmayr, R., Satow, K., Zheng, J., and Dahl-Jensen, D.: Densification of layered firn of the ice sheet at NEEM, Greenland, J. Glaciol., 60, 905-921, doi:10.3189/2014JoG14J006, 2014.

Goujon, C., Barnola, J. M., and Ritz, C.: Modeling the densification of polar firn including heat diffusion: Application to closeoff characteristics and gas isotopic fractionation for Antarctica and Greenland sites, J. Geophys. Res.-Atmos., 108, 18 pp., doi:10.1029/2002jd003319, 2003.

Gow, A. J., Meese, D. A., Alley, R. B., Fitzpatrick, J. J., Anandakrishnan, S., Woods, G. A., and Elder, B. C.: Physical and structural properties of the Greenland Ice Sheet Project 2 ice core: a review, J. Geophys. Res.-Oceans, 102, 26559-26575, 1997.

Gundestrup, N. S., Dahl-Jensen, D., Hansen, B. L., and Kelty, J.: Bore-hole survey at Camp Century, 1989, Cold Reg. Sci. Technol., 21, 187-193, 1993.

Herron, M. M. and Langway, C. C.: Firn densification: an empirical model, J. Glaciol., 25, 373-385, 1980.

Horhold, M. W., Laepple, T., Freitag, J., Bigler, M., Fischer, H., and Kipfstuhl, S.: On the impact of impurities on the densification of polar firn, Earth Planet. Sc. Lett., 325-326, 93-99, 2012.

Huber, C., Leuenberger, M., Spahni, R., Fluckiger, J., Schwander, J., Stocker, T. F., Johnsen, S., Landals, A., and Jouzel, J.: Isotope calibrated Greenland temperature record over Marine Isotope Stage 3 and its relation to $\mathrm{CH}_{4}$, Earth Planet. Sc. Lett., 243, 504-519, 2006.

Johnsen, S. J., Dahl-Jensen, D., Gundestrup, N., Steffensen, J. P., Clausen, H. B., Miller, H., Masson-Delmotte, V., Sveinbjörnsdottir, A. E., and White, J.: Oxygen isotope and palaeotemperature records from six Greenland ice-core stations: Camp Century, Dye-3, GRIP, GISP2, Renland and NorthGRIP, J. Quaternary Sci., 16, 299-307, 2001.
Kanner, L. C., Burns, S. J., Cheng, H., and Edwards, R. L.: Highlatitude forcing of the south American summer monsoon during the last glacial, Science, 335, 570-573, 2012.

Kaspers, K. A., van de Wal, R. S. W., van den Broeke, M. R., Schwander, J., van Lipzig, N. P. M., and Brenninkmeijer, C. A. M.: Model calculations of the age of firn air across the Antarctic continent, Atmos. Chem. Phys., 4, 1365-1380, doi:10.5194/acp-4-1365-2004, 2004.

Kawamura, K., Severinghaus, J. P., Ishidoya, S., Sugawara, S., Hashida, G., Motoyama, H., Fujii, Y., Aoki, S., and Nakazawa, T.: Convective mixing of air in firn at four polar sites, Earth Planet. Sc. Lett., 244, 672-682, 2006.

Kawamura, K., Parrenin, F., Lisiecki, L., Uemura, R., Vimeux, F., Severinghaus, J. P., Hutterli, M. A., Nakazawa, T., Aoki, S., Jouzel, J., Raymo, M. E., Matsumoto, K., Nakata, H., Motoyama, H., Fujita, S., Goto-Azuma, K., Fujii, Y., and Watanabe, O.: Northern Hemisphere forcing of climatic cycles in Antarctica over the past 360000 years, Nature, 448, 912-916, 2007.

Kindler, P., Guillevic, M., Baumgartner, M., Schwander, J., Landais, A., and Leuenberger, M.: Temperature reconstruction from 10 to $120 \mathrm{kyr}$ b2k from the NGRIP ice core, Clim. Past, 10, 887-902, doi:10.5194/cp-10-887-2014, 2014.

Lal, D., Jull, A. J. T., Donahue, D. J., Burtner, D., and Nishiizumi, K.: Polar ice ablation rates measured using in situ cosmogenic C-14, Nature, 346, 350-352, 1990.

Landais, A., Barnola, J. M., Kawamura, K., Caillon, N., Delmotte, M., Van Ommen, T., Dreyfus, G., Jouzel, J., MassonDelmotte, V., Minster, B., Freitag, J., Leuenberger, M., Schwander, J., Huber, C., Etheridge, D., and Morgan, V.: Firn-air delta $\mathrm{N}-15$ in modern polar sites and glacial-interglacial ice: a modeldata mismatch during glacial periods in Antarctica?, Quaternary Sci. Rev., 25, 49-62, 2006.

Marcott, S. A., Bauska, T. K., Buizert, C., Steig, E. J., Rosen, J. L., Cuffey, K. M., Fudge, T. J., Severinghaus, J. P., Ahn, J., Kalk, M. L., McConnell, J. R., Sowers, T., Taylor, K. C., White, J. W. C., and Brook, E. J.: Centennial-scale changes in the global carbon cycle during the last deglaciation, Nature, 514, 616-619, 2014.

Martinerie, P., Lipenkov, V. Y., Raynaud, D., Chappellaz, J., Barkov, N. I., and Lorius, C.: Air content paleo record in the Vostok ice core (Antarctica): A mixed record of climatic and glaciological parameters, J. Geophys. Res.-Atmos., 99, 10565-10576, 1994.

McConnell, J. R., Lamorey, G. W., Lambert, S. W., and Taylor, K. C.: Continuous ice-core chemical analyses using inductively coupled plasma mass spectrometry, Environ. Sci. Technol., 36, 7-11, 2002.

McConnell, J. R., Edwards, R., Kok, G. L., Flanner, M. G., Zender, C. S., Saltzman, E. S., Banta, J. R., Pasteris, D. R., Carter, M. M., and Kahl, J. D. W.: 20th-century industrial black carbon emissions altered arctic climate forcing, Science, 317, 1381-1384, 2007

McManus, J. F., Francois, R., Gherardi, J. M., Keigwin, L. D., and Brown-Leger, S.: Collapse and rapid resumption of Atlantic meridional circulation linked to deglacial climate changes, Nature, 428, 834-837, 2004.

Mischler, J. A., Sowers, T. A., Alley, R. B., Battle, M., McConnell, J. R., Mitchell, L., Popp, T., Sofen, E., and 
Spencer, M. K.: Carbon and hydrogen isotopic composition of methane over the last 1000 years, Global Biogeochem. Cy., 23, GB4024, doi:10.1029/2009gb003460, 2009.

Mitchell, L., Brook, E., Lee, J. E., Buizert, C., and Sowers, T.: Constraints on the late holocene anthropogenic contribution to the atmospheric methane budget, Science, 342, 964-966, 2013.

Mitchell, L. E., Brook, E. J., Sowers, T., McConnell, J. R., and Taylor, K.: Multidecadal variability of atmospheric methane, 1000-1800 C.E, J. Geophys. Res., 116, G02007, doi:10.1029/2010jg001441, 2011.

NEEM community members: Eemian interglacial reconstructed from a Greenland folded ice core, Nature, 493, 489-494, 2013.

NGRIP community members: High-resolution record of Northern Hemisphere climate extending into the last interglacial period, Nature, 431, 147-151, 2004.

Orsi, A. J.: Temperature reconstruction at the West Antarctic Ice Sheet Divide, for the last millennium, from the combination of borehole temperature and inert gas isotope measurements, Ph. D. thesis, University of California, San Diego, 2013.

Parrenin, F., Barker, S., Blunier, T., Chappellaz, J., Jouzel, J., Landais, A., Masson-Delmotte, V., Schwander, J., and Veres, D.: On the gas-ice depth difference ( $\Delta$ depth) along the EPICA Dome C ice core, Clim. Past, 8, 1239-1255, doi:10.5194/cp-8-12392012, 2012.

Parrenin, F., Masson-Delmotte, V., Kohler, P., Raynaud, D., Paillard, D., Schwander, J., Barbante, C., Landais, A., Wegner, A., and Jouzel, J.: Synchronous change of atmospheric $\mathrm{CO}_{2}$ and antarctic temperature during the last deglacial warming, Science, 339, 1060-1063, 2013.

Pedro, J. B., van Ommen, T. D., Rasmussen, S. O., Morgan, V. I., Chappellaz, J., Moy, A. D., Masson-Delmotte, V., and Delmotte, M.: The last deglaciation: timing the bipolar seesaw, Clim. Past, 7, 671-683, doi:10.5194/cp-7-671-2011, 2011.

Pedro, J. B., Rasmussen, S. O., and van Ommen, T. D.: Tightened constraints on the time-lag between Antarctic temperature and $\mathrm{CO}_{2}$ during the last deglaciation, Clim. Past, 8, 1213-1221, doi:10.5194/cp-8-1213-2012, 2012.

Petrenko, V. V., Severinghaus, J. P., Brook, E. J., Reeh, N., and Schaefer, H.: Gas records from the West Greenland ice margin covering the Last Glacial Termination: a horizontal ice core, Quaternary Sci. Rev., 25, 865-875, 2006.

Rasmussen, S. O., Andersen, K. K., Svensson, A. M., Steffensen, J. P., Vinther, B. M., Clausen, H. B., SiggaardAndersen, M. L., Johnsen, S. J., Larsen, L. B., Dahl-Jensen, D., Bigler, M., Röthlisberger, R., Fischer, H., Goto-Azuma, K., Hansson, M. E., and Ruth, U.: A new Greenland ice core chronology for the last glacial termination, J. Geophys. Res., 111, D06102, doi:10.1029/2005jd006079, 2006.

Rasmussen, S. O., Abbott, P. M., Blunier, T., Bourne, A. J., Brook, E., Buchardt, S. L., Buizert, C., Chappellaz, J., Clausen, H. B., Cook, E., Dahl-Jensen, D., Davies, S. M., Guillevic, M., Kipfstuhl, S., Laepple, T., Seierstad, I. K., Severinghaus, J. P., Steffensen, J. P., Stowasser, C., Svensson, A., Vallelonga, P., Vinther, B. M., Wilhelms, F., and Winstrup, M.: A first chronology for the North Greenland Eemian Ice Drilling (NEEM) ice core, Clim. Past, 9, 2713-2730, doi:10.5194/cp-92713-2013, 2013.

Rasmussen, S. O., Bigler, M., Blockley, S. P., Blunier, T., Buchardt, S. L., Clausen, H. B., Cvijanovic, I., Dahl-Jensen, D., Johnsen,
S. J., Fischer, H., Gkinis, V., Guillevic, M., Hoek, W. Z., Lowe, J. J., Pedro, J. B., Popp, T., Seierstad, I. K., Steffensen, J. P., Svensson, A. M., Vallelonga, P., Vinther, B. M., Walker, M. J., Wheatley, J. J., and Winstrup, M.: A stratigraphic framework for abrupt climatic changes during the Last Glacial period based on three synchronized Greenland ice-core records: refining and extending the INTIMATE event stratigraphy, Quaternary Sci. Rev., 106, 14-28, 2014.

Reimer, P., Bard, E., Bayliss, A., Beck, J., Blackwell, P., Ramsey, C. B., Buck, C., Cheng, H., Edwards, R. L., Friedrich, M., Grootes, P., Guilderson, T., Haflidason, H., Hajdas, I., Hatté, C., Heaton, T., Hoffmann, D., Hogg, A., Hughen, K., Kaiser, K., Kromer, B., Manning, S., Niu, M., Reimer, R., Richards, D., Scott, E., Southon, J., Staff, R., Turney, C., and van der Plicht, J.: IntCal13 and Marine13 Radiocarbon Age Calibration Curves 0-50 000 Years cal BP, Radiocarbon, 55, 1869-1887, 2013.

Rhodes, R. H., Fain, X., Stowasser, C., Blunier, T., Chappellaz, J., McConnell, J. R., Romanini, D., Mitchell, L. E., and Brook, E. J.: Continuous methane measurements from a late Holocene Greenland ice core: atmospheric and in-situ signals, Earth Planet. Sc. Lett., 368, 9-19, 2013.

Rhodes, R. H. Brook, E. J., Chiang, J. C. H., Blunier, T., Maselli, O. J., McConnell, J. R., Romanini, D., Severinghaus, J. P.: Enhanced tropical methane production in response to iceberg discharge in the North Atlantic, in review, 2015.

Rosen, J. L., Brook, E. J., Severinghaus, J. P., Blunier, T., Mitchell, L. E., Lee, J. E., Edwards, J. S., and Gkinis, V.: An ice core record of near-synchronous global climate changes at the Bolling transition, Nat. Geosci., 7, 459-463, 2014.

Schwander, J. and Stauffer, B.: Age difference between polar ice and the air trapped in its bubbles, Nature, 311, 45-47, 1984.

Schwander, J., Sowers, T., Barnola, J. M., Blunier, T., Fuchs, A., and Malaize, B.: Age scale of the air in the summit ice: Implication for glacial-interglacial temperature change, J. Geophys. Res.-Atmos., 102, 19483-19493, 1997.

Seierstad, I., Abbott, P., Bigler, M., Blunier, T., Bourne, A., Brook, E., Buchardt, S. L., Buizert, C., Clausen, H. B., Cook, E., Dahl-Jensen, D., Davies, S., Guillevic, M., Johnsen, S., Pedersen, D., Popp, T., Rasmussen, S. O., Severinghaus, J., Svensson, A., and Vinther, B.: Consistently dated records from the Greenland GRIP, GISP2 and NGRIP ice cores for the past $104 \mathrm{ka}$ reveal regional millennial-scale isotope gradients with possible Heinrich Event imprint, Quaternary Sci. Rev., 106, 29-46, 2014

Severi, M., Becagli, S., Castellano, E., Morganti, A., Traversi, R., Udisti, R., Ruth, U., Fischer, H., Huybrechts, P., Wolff, E., Parrenin, F., Kaufmann, P., Lambert, F., and Steffensen, J. P.: Synchronisation of the EDML and EDC ice cores for the last 52 kyr by volcanic signature matching, Clim. Past, 3, 367-374, doi:10.5194/cp-3-367-2007, 2007.

Severinghaus, J. P., Beaudette, R., Headly, M. A., Taylor, K., and Brook, E. J.: Oxygen-18 of $\mathrm{O}_{2}$ records the impact of abrupt climate change on the terrestrial biosphere, Science, 324, 14311434, 2009.

Sigl, M., McConnell, J. R., Layman, L., Maselli, O., McGwire, K., Pasteris, D., Dahl-Jensen, D., Steffensen, J. P., Vinther, B., Edwards, R., Mulvaney, R., and Kipfstuhl, S.: A new bipolar ice core record of volcanism from WAIS Divide and NEEM and implications for climate forcing of the last 2000 years, J. Geophys. Res.-Atmos., 118, 1151-1169, 2013. 
Sigl, M., McConnell, J. R., Toohey, M., Curran, M., Das, S. B., Edwards, R., Isaksson, E., Kawamura, K., Kipfstuhl, S., Krüger, K., Layman, L., Maselli, O. J., Motizuki, Y., Motoyama, H., Pasteris, D. R., and Severi, M.: Insights from Antarctica on volcanic forcing during the Common Era, Nat. Clim. Change, 4, 693-697, 2014.

Southon, J., Noronha, A. L., Cheng, H., Edwards, R. L., and Wang, Y.: A high-resolution record of atmospheric ${ }^{14} \mathrm{C}$ based on Hulu Cave speleothem H82, Quaternary Sci. Rev., 33, 32-41, 2012.

Sowers, T., Bender, M., and Raynaud, D.: Elemental and isotopic composition of occluded $\mathrm{O}_{2}$ and $\mathrm{N}_{2}$ in polar ice, J. Geophys. Res.-Atmos., 94, 5137-5150, 1989.

Sowers, T., Bender, M., Raynaud, D., and Korotkevich, Y. S.: $\delta^{15} \mathrm{~N}$ of $\mathrm{N}_{2}$ in air trapped in polar ice: A tracer of gas transport in the firn and a possible constraint on ice age-gas age differences, J. Geophys. Res.-Atmos., 97, 15683-15697, 1992.

Steig, E. J., Ding, Q., White, J. W. C., Kuttel, M., Rupper, S. B., Neumann, T. A., Neff, P. D., Gallant, A. J. E., Mayewski, P. A., Taylor, K. C., Hoffmann, G., Dixon, D. A., Schoenemann, S. W., Markle, B. R., Fudge, T. J., Schneider, D. P., Schauer, A. J., Teel, R. P., Vaughn, B. H., Burgener, L., Williams, J., and Korotkikh, E.: Recent climate and ice-sheet changes in West Antarctica compared with the past 2000 years, Nat. Geosci., 6, 372-375, 2013.

Stocker, T. F. and Johnsen, S. J.: A minimum thermodynamic model for the bipolar seesaw, Paleoceanography, 18, 1087, doi:10.1029/2003pa000920, 2003.

Stowasser, C., Buizert, C., Gkinis, V., Chappellaz, J., Schüpbach, S., Bigler, M., Faïn, X., Sperlich, P., Baumgartner, M., Schilt, A., and Blunier, T.: Continuous measurements of methane mixing ratios from ice cores, Atmos. Meas. Tech., 5, 999-1013, 2012, http://www.atmos-meas-tech.net/5/999/2012/.

Svensson, A., Andersen, K. K., Bigler, M., Clausen, H. B., Dahl-Jensen, D., Davies, S. M., Johnsen, S. J., Muscheler, R., Rasmussen, S. O., Rothlisberger, R., Steffensen, J. P., and Vinther, B. M.: The Greenland Ice Core Chronology 2005, 1542 ka. Part 2: Comparison to other records, Quaternary Sci. Rev., 25, 3258-3267, 2006.
Veres, D., Bazin, L., Landais, A., Toyé Mahamadou Kele, H., Lemieux-Dudon, B., Parrenin, F., Martinerie, P., Blayo, E., Blunier, T., Capron, E., Chappellaz, J., Rasmussen, S. O., Severi, M., Svensson, A., Vinther, B., and Wolff, E. W.: The Antarctic ice core chronology (AICC2012): an optimized multi-parameter and multi-site dating approach for the last 120 thousand years, Clim. Past, 9, 1733-1748, doi:10.5194/cp-9-1733-2013, 2013.

Voelker, A. H. L.: Global distribution of centennial-scale records for Marine Isotope Stage (MIS) 3: A database, Quaternary Sci. Rev., 21, 1185-1212, 2002.

WAIS Divide Project Members: Onset of deglacial warming in West Antarctica driven by local orbital forcing, Nature, 500, 440-444, 2013.

WAIS Divide Project Members: Precise interpolar phasing of abrupt climate change during the last ice age, in press, 2015.

Wang, X. F., Auler, A. S., Edwards, R. L., Cheng, H., Ito, E., and Solheid, M.: Interhemispheric anti-phasing of rainfall during the last glacial period, Quaternary Sci. Rev., 25, 3391-3403, 2006.

Wang, Y. J., Cheng, H., Edwards, R. L., An, Z. S., Wu, J. Y., Shen, C. C., and Dorale, J. A.: A high-resolution absolute-dated late pleistocene monsoon record from Hulu Cave, China, Science, 294, 2345-2348, 2001.

Winstrup, M., Svensson, A. M., Rasmussen, S. O., Winther, O., Steig, E. J., and Axelrod, A. E.: An automated approach for annual layer counting in ice cores, Clim. Past, 8, 1881-1895, doi:10.5194/cp-8-1881-2012, 2012.

Wolff, E. W., Fischer, H., Fundel, F., Ruth, U., Twarloh, B., Littot, G. C., Mulvaney, R., Rothlisberger, R., de Angelis, M., Boutron, C. F., Hansson, M., Jonsell, U., Hutterli, M. A., Lambert, F., Kaufmann, P., Stauffer, B., Stocker, T. F., Steffensen, J. P., Bigler, M., Siggaard-Andersen, M. L., Udisti, R., Becagli, S., Castellano, E., Severi, M., Wagenbach, D., Barbante, C., Gabrielli, P., and Gaspari, V.: Southern Ocean sea-ice extent, productivity and iron flux over the past eight glacial cycles, Nature, 440, 491-496, 2006.

Wolff, E. W., Chappellaz, J., Blunier, T., Rasmussen, S. O., and Svensson, A.: Millennial-scale variability during the last glacial: the ice core record, Quaternary Sci. Rev., 29, 2828-2838, 2010. 